\title{
Chemistry of new particle growth in mixed urban and biogenic emissions - insights from CARES
}

\author{
A. Setyan ${ }^{1, *}$, C. Song ${ }^{2}$, M. Merkel ${ }^{3}$, W. B. Knighton ${ }^{4}$, T. B. Onasch ${ }^{5}$, M. R. Canagaratna ${ }^{5}$, D. R. Worsnop ${ }^{5,6}$, \\ A. Wiedensohler ${ }^{3}$, J. E. Shilling ${ }^{2}$, and Q. Zhang ${ }^{1}$ \\ ${ }^{1}$ Department of Environmental Toxicology, 1 Shields Ave., University of California, Davis, CA 95616, USA \\ ${ }^{2}$ Atmospheric Sciences and Global Change Division, Pacific Northwest National Laboratory, Richmond, WA 99352, USA \\ ${ }^{3}$ Leibniz Institute for Tropospheric Research, 04318 Leipzig, Germany \\ ${ }^{4}$ Montana State University, Bozeman, MT 59717, USA \\ ${ }^{5}$ Aerodyne Research Inc., Billerica, MA 01821, USA \\ ${ }^{6}$ Department of Physics, University of Helsinki, 00014 Helsinki, Finland \\ * now at: Empa, Swiss Federal Laboratories for Materials Science and Technology, 8600 Dübendorf, Switzerland
}

Correspondence to: Q. Zhang (dkwzhang @ucdavis.edu)

Received: 29 December 2013 - Published in Atmos. Chem. Phys. Discuss.: 23 January 2014

Revised: 20 May 2014 - Accepted: 26 May 2014 - Published: 1 July 2014

\begin{abstract}
Regional new particle formation and growth events (NPEs) were observed on most days over the Sacramento and western Sierra foothills area of California in June 2010 during the Carbonaceous Aerosols and Radiative Effect Study (CARES). Simultaneous particle measurements at both the T0 (Sacramento, urban site) and the T1 (Cool, rural site located $\sim 40 \mathrm{~km}$ northeast of Sacramento) sites of CARES indicate that the NPEs usually occurred in the morning with the appearance of an ultrafine mode at $\sim 15 \mathrm{~nm}$ (in mobility diameter, $D_{\mathrm{m}}$, measured by a mobility particle size spectrometer operating in the range $10-858 \mathrm{~nm}$ ) followed by the growth of this modal diameter to $\sim 50 \mathrm{~nm}$ in the afternoon. These events were generally associated with southwesterly winds bringing urban plumes from Sacramento to the T1 site. The growth rate was on average higher at $\mathrm{T} 0\left(7.1 \pm 2.7 \mathrm{~nm} \mathrm{~h}^{-1}\right)$ than at $\mathrm{T} 1$ $\left(6.2 \pm 2.5 \mathrm{~nm} \mathrm{~h}^{-1}\right)$, likely due to stronger anthropogenic influences at T0. Using a high-resolution time-of-flight aerosol mass spectrometer (HR-ToF-AMS), we investigated the evolution of the size-resolved chemical composition of new particles at T1. Our results indicate that the growth of new particles was driven primarily by the condensation of oxygenated organic species and, to a lesser extent, ammonium sulfate. New particles appear to be fully neutralized during growth, consistent with high $\mathrm{NH}_{3}$ concentration in the region. Nitrogen-containing organic ions (i.e., $\mathrm{CHN}^{+}, \mathrm{CH}_{4} \mathrm{~N}^{+}$,
\end{abstract}

$\mathrm{C}_{2} \mathrm{H}_{3} \mathrm{~N}^{+}$, and $\mathrm{C}_{2} \mathrm{H}_{4} \mathrm{~N}^{+}$) that are indicative of the presence of alkyl-amine species in submicrometer particles enhanced significantly during the NPE days, suggesting that amines might have played a role in these events. Our results also indicate that the bulk composition of the ultrafine mode organics during NPEs was very similar to that of anthropogenically influenced secondary organic aerosol (SOA) observed in transported urban plumes. In addition, the concentrations of species representative of urban emissions (e.g., black carbon, $\mathrm{CO}, \mathrm{NO}_{\mathrm{x}}$, and toluene) were significantly higher whereas the photo-oxidation products of biogenic VOCs (volatile organic compounds) and the biogenically influenced SOA also increased moderately during the NPE days compared to the non-event days. These results indicate that the frequently occurring NPEs over the Sacramento and Sierra Nevada regions were mainly driven by urban plumes from Sacramento and the San Francisco Bay Area, and that the interaction of regional biogenic emissions with the urban plumes has enhanced the new particle growth. This finding has important implications for quantifying the climate impacts of NPEs on global scale. 


\section{Introduction}

New particle formation and growth processes are an important source of ultrafine particles in both clean and polluted environments. A large number of studies reported the observations of intensive new particle events at various locations, including urban areas (e.g., Brock et al., 2003; Dunn et al., 2004; Stanier et al., 2004; Zhang et al., 2004a; Wu et al., 2007; Ahlm et al., 2012), remote sites (e.g., Weber et al., 1999; Creamean et al., 2011; Vakkari et al., 2011; Pikridas et al., 2012), forested locations (e.g., Allan et al., 2006; Pierce et al., 2012; Han et al., 2013), coastal sites (e.g., O'Dowd et al., 2002; Wen et al., 2006; Liu et al., 2008; Modini et al., 2009), and polar regions (e.g., Komppula et al., 2003; Koponen et al., 2003; Asmi et al., 2010). These events significantly affect the number concentrations and size distributions of particles in the atmosphere with important implications for human health and climate (Spracklen et al., 2006; Bzdek and Johnston, 2010; Kerminen et al., 2012). However, despite frequent observations, the chemical processes underlying the formation and growth of new particles remain poorly understood.

New particle events occur in two steps, i.e., the formation of nuclei, followed by the growth of the stable clusters to larger sizes by condensation of low-volatility compounds and coagulation. For ambient measurements, the evolution of the number-based particle size distribution is a main criterion for identifying the onset of new particle events. Mobility particle size spectrometer (MPSS), also called scanning mobility particle sizer (SMPS), is the most widely used instrument to determine the particle number concentration and size distribution during these events. The evolution of the chemical composition of ultrafine particles during new particle formation and growth is another piece of critical information needed for understanding this process. For that purpose, aerosol mass spectrometer (AMS) (e.g., Zhang et al., 2004a; Allan et al., 2006; Ziemba et al., 2010; Creamean et al., 2011; Ahlm et al., 2012), chemical ionization mass spectrometer (CIMS) (e.g., Dunn et al., 2004; Smith et al., 2005, 2008, 2010; Jokinen et al., 2012), Nano aerosol mass spectrometer (NAMS) (e.g., Bzdek et al., 2011; Bzdek et al., 2012), and atmospheric pressure ionization time-of-flight (APi-TOF) mass spectrometer (Lehtipalo et al., 2011; Kulmala et al., 2013) have been successfully deployed in the field to study the chemical processes underlying atmospheric new particle events.

An important finding from previous studies is that organics and sulfates are usually involved in the growth of new particles up to sizes where they can act as cloud condensation nuclei $(\mathrm{CCN})$. The contribution of these two species to particle growth depends on the concentrations of the precursors and meteorological conditions. For example, at urban or industrial locations where the $\mathrm{SO}_{2}$ mixing ratio is high, sulfate is an important contributor to the growth of new particles (Brock et al., 2003; Zhang et al., 2004a; Yue et al., 2010; Bzdek et al., 2012). At rural and remote locations, however, the growth of new particles was found to be almost exclusively driven by organics (Smith et al., 2008; Laaksonen et al., 2008; Ziemba et al., 2010; Pierce et al., 2012; Ahlm et al., 2012). In addition, it was found that in Pittsburgh, USA, despite high ambient $\mathrm{SO}_{2}$ concentrations, $\mathrm{H}_{2} \mathrm{SO}_{4}$ contributes mainly to the early stage of the new particle growth, while the growth up to $\mathrm{CCN}$ sizes is mainly driven by secondary organic aerosols (SOA), especially during late morning and afternoon when photochemistry is more intense (Zhang et al., 2004a, 2005).

SOA is a major component of fine particles globally (Zhang et al., 2007; Jimenez et al., 2009). Understanding its roles in new particle formation and growth is important for addressing aerosols' effects on climate and human health. Recent studies found significantly enhanced SOA formation rates in mixed biogenic and anthropogenic emissions (de Gouw et al., 2005; Volkamer et al., 2006; Kleinman et al., 2008; Setyan et al., 2012; Shilling et al., 2013). However, there is little known about the influence of the interactions of organic species from biogenic and anthropogenic sources on new particle growth. The Sacramento Valley in California is a place of choice to study this process. The Sacramento metropolitan area lies in the Central Valley to the north of the San Joaquin River delta and to the southwest of the forested Sierra Nevada mountains. The wind in this region is characterized by a very regular pattern, especially in summer (Fast et al., 2012). Indeed, during the day, a southwesterly wind usually brings air masses from the San Francisco Bay to the Sacramento metropolitan area and pushes northeast to the Sierra Nevada mountains (Dillon et al., 2002), promoting the transport of urban plumes from Sacramento and the bay area to forested regions where biogenic emissions are intense.

The US Department of Energy (DOE) sponsored Carbonaceous Aerosols and Radiative Effects Study (CARES) that took place in the Sacramento Valley in June 2010 was designed to take advantage of this regular wind pattern to better understand the life-cycle processes and radiative properties of carbonaceous aerosols in a region influenced by both anthropogenic and biogenic emissions (Zaveri et al., 2012). Within the framework of CARES, a wide range of instruments were deployed between 2 and 28 June 2010 at two ground sites located in Sacramento (T0, urban site) and Cool, $\mathrm{CA}$ at the foothills of the Sierra Nevada mountains (T1, rural site), to measure size-resolved chemical compositions, number size distributions, and optical and hygroscopic properties of aerosols, as well as trace gases and meteorological data (Zaveri et al., 2012). One of the major observations during CARES was that particles were dominated by organics, and that the formation of SOA was enhanced when anthropogenic emissions from the Sacramento metropolitan area and the Bay Area were transported to the foothills and mixed with biogenic emissions (Setyan et al., 2012; Shilling et al., 2013).

During CARES, new particle growth events were observed almost daily at both the $\mathrm{T} 0$ and $\mathrm{T} 1$ sites. Similarly, previous 
studies conducted at the University of California Blodgett Forest Research Station, approximately $75 \mathrm{~km}$ to the northeast of Sacramento and $35 \mathrm{~km}$ to the northeast of the T1 site, also reported the frequent occurrence of NPEs (Lunden et al., 2006; Creamean et al., 2011). In their study conducted from May to September 2002, Lunden et al. (2006) found that the oxidation products of reactive biogenic compounds accounted for a significant portion of the particle growth. The study of Creamean et al. (2011), which took place in early spring of 2009, found that sulfates and amines participated in the growth of new particles and that long-range transport of $\mathrm{SO}_{2}$ from Asia seemed to contribute to faster growth. These findings indicate that new particle formation and growth are important processes in Northern California and are affected by regional anthropogenic and biogenic emissions as well as by pollutants transported from Asia. Understanding to what extent these emissions may govern the NPEs requires measurements of size-resolved chemical compositions of the new particles. The main aim of the present paper is to examine the evolution characteristics of new particles at the T0 and T1 sites during CARES, with a focus on the evolution of sizeresolved particle chemical composition based on HR-ToFAMS measurements at $\mathrm{T} 1$.

\section{Experimental}

\subsection{Sampling site and instrumentation}

The T0 sampling site was located on the campus of the American River College in Sacramento $\left(38^{\circ} 39^{\prime} 01^{\prime \prime} \mathrm{N}\right.$, $121^{\circ} 20^{\prime} 49^{\prime \prime} \mathrm{W}, 30 \mathrm{~m}$ above sea level) and the T1 site was located on the campus of the Northside School at Cool $\left(38^{\circ} 52^{\prime} 16^{\prime \prime} \mathrm{N}, 121^{\circ} 01^{\prime} 22^{\prime \prime} \mathrm{W}, 450 \mathrm{~m}\right.$ above sea level). Sacramento is the capital of California, with 480000 inhabitants in the city and 2.5 million people living in the metropolitan area. Cool is a small town (2500 inhabitants) surrounded by very large forested areas, and located $\sim 40 \mathrm{~km}$ northeast of Sacramento at the Sierra Nevada foothills.

In this paper, we report results of particle chemical compositions at $\mathrm{T} 1$, and particle number size distributions at both T0 and T1. Size-resolved chemical composition of nonrefractory submicron aerosols $\left(\mathrm{NR}-\mathrm{PM}_{1}\right)$ were measured at T1 using an Aerodyne HR-AMS (DeCarlo et al., 2006; Canagaratna et al., 2007). A detailed discussion on its operation during the present study was presented in Setyan et al. (2012). Briefly, the HR-AMS was equipped with a standard aerodynamic lens, described in Zhang et al. (2004b), and allowing the transmission of particles in the range $\sim 30$ $1500 \mathrm{~nm}$ (in vacuum aerodynamic diameter, $D_{\text {va }}$ ). The instrument was operated alternatively in $\mathrm{V}$ - and $\mathrm{W}$-mode every $2.5 \mathrm{~min}$. In V-mode, data was recorded in mass spectrum (MS) mode and particle time-of-flight (PToF) mode. The MS mode was used to obtain average mass spectra and determine the concentration of the species in submicrometer particles without size information. In the PToF mode, average mass spectra were acquired for 92 size bins covering $30-1500 \mathrm{~nm}$ $\left(D_{\text {va }}\right)$, allowing the determination of the size-resolved chemical composition. W-mode data was recorded exclusively in MS mode.

The particle number size distribution was measured both at T0 and T1 with a MPSS (also called SMPS) as described in Wiedensohler et al. (2012). The instrument used at T1 consists of a Hauke-type differential mobility analyzer (DMA) and a condensation particle counter (CPC; TSI Inc., Shoreview, MN; model 3772 ), and used ${ }^{210} \mathrm{Po}$ as a radioactive source for the neutralizer (Setyan et al., 2012). The MPSS was set to measure particles in the range $10-858 \mathrm{~nm}$ (in mobility diameter, $D_{\mathrm{m}}$ ), divided into 70 logarithmically distributed size bins. MPSS data has been corrected to take into account the DMA-CPC lag time, bipolar charge distribution, CPC efficiency, and diffusion loss. The SMPS deployed at T0 was a commercial instrument (TSI Inc.; model 3936), and was constituted of a ${ }^{85} \mathrm{Kr}$ neutralizer, a DMA (TSI Inc.; model 3080 with the long column) and a CPC (TSI Inc.; model 3775). The instrument measured particles in the size range of $12-737 \mathrm{~nm}$ (in $D_{\mathrm{m}}$ ) divided into 115 size bins. Diffusion loss correction was applied after the data inversion. All dates and times reported in this paper are in Pacific Daylight Time (PDT = UTC $-7 \mathrm{~h}$ ), which was the local time during this study.

\subsection{Data analysis}

Particle number concentration and size distribution have been used to identify new particle events in the atmosphere. However, given that the new particles formed by nucleation have generally a diameter in the size range $1-3 \mathrm{~nm}$, smaller than the smallest size measured by our MPSSs, we were not able to observe the new particle formation themselves during the present study, but only the growth of the newly formed particles that are larger than $10 \mathrm{~nm}$. For this reason, we will not use the terms "nucleation" or "new particle formation" in the forthcoming discussion, but rather "new particle growth". Each day for which complete MPSS data was available was classified as new particle event (NPE) day if the particle number concentration in the size range $12-20 \mathrm{~nm}$ increased by more than 800 particles $\mathrm{cm}^{-3}$, and if this increase was accompanied by the increase of the modal diameter during the following hours. These two conditions allowed us to distinguish NPEs from primary emissions from vehicles, which also produce small particles but are usually observed as occasional spikes in the time series of the particle number concentration in the range $12-20 \mathrm{~nm}$. In addition, each growth event was considered as "strong" if the increase of the particle number concentration in the range $12-20 \mathrm{~nm}$ was higher than 1500 particles $\mathrm{cm}^{-3}$, and "weak" if the increase was lower than this threshold. A summary of the new particle growth events observed during this study is provided in Table 1. 


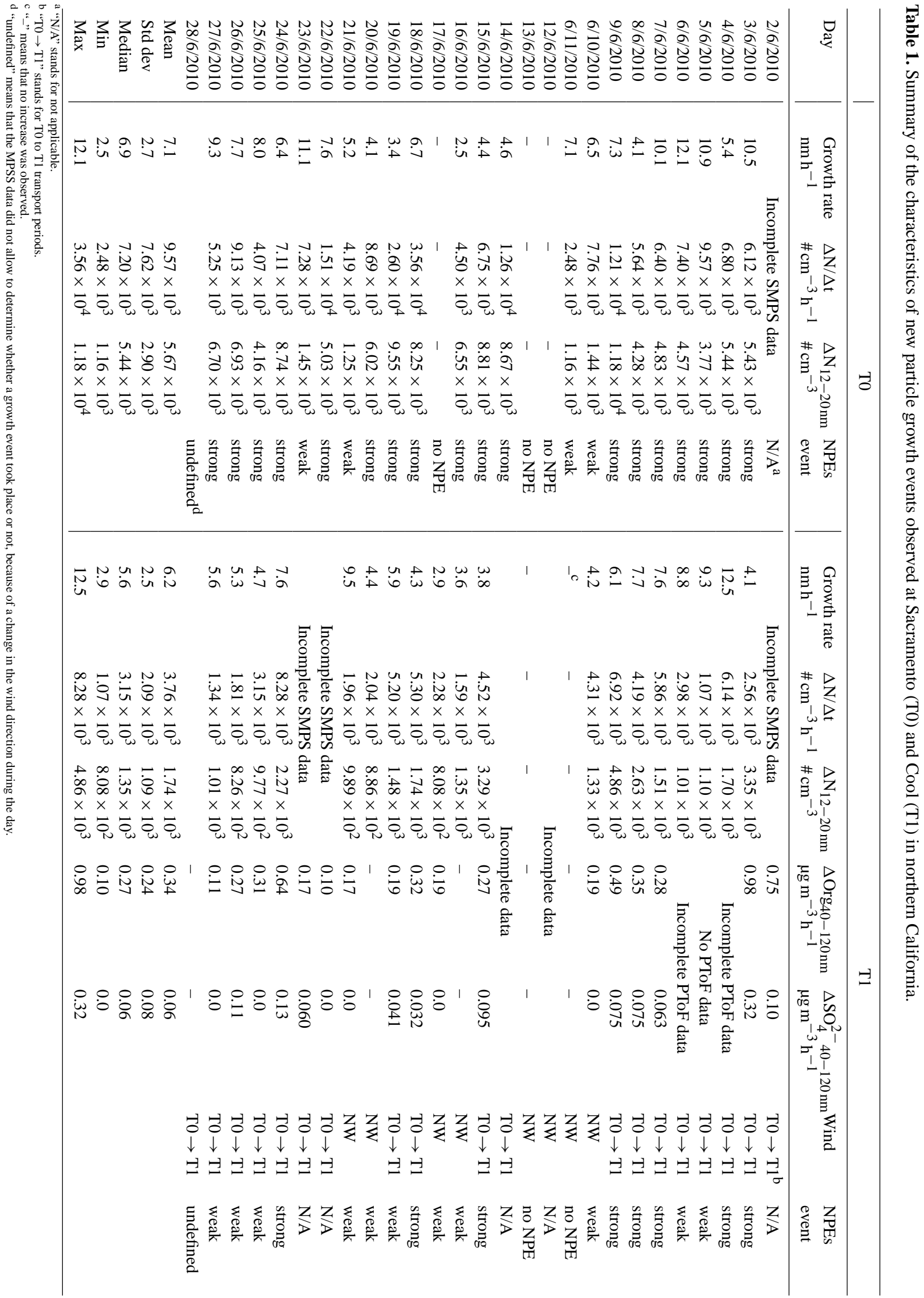




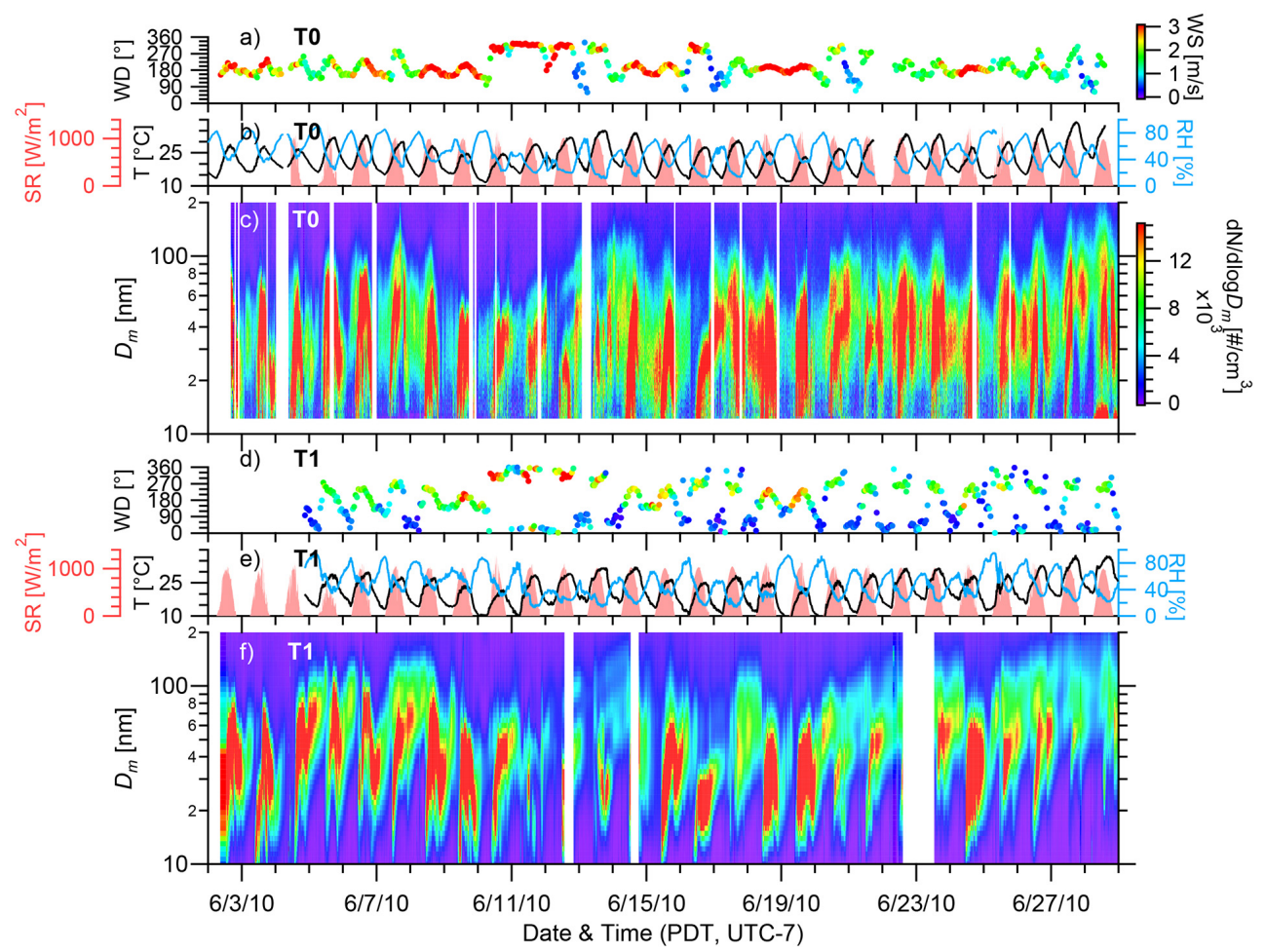

Figure 1. Time series of (a, d) wind direction colored by wind speed, $(\mathbf{b}, \mathbf{e})$ broadband solar radiation, temperature and relative humidity, and $(\mathbf{c}, \mathbf{f})$ particle size distributions at the $\mathrm{T} 0$ and $\mathrm{T} 1$ sites.

The modal diameter(s) of each particle number size distribution recorded during this study have been determined with a multiple peak fitting tool available in Igor Pro 6.2.2.2 (WaveMetrics Inc., Lake Oswego, OR). All the size distributions were log normal. The growth rate (GR), which corresponds to the increase of the modal diameter of newly formed particles per time unit $\left(\mathrm{nm} \mathrm{h}^{-1}\right)$, has been calculated for each individual growth event using Eq. (1):

$\mathrm{GR}=\frac{\Delta D_{\mathrm{m}}}{\Delta t}$

in which $\Delta D_{\mathrm{m}}$ is the difference of the modal diameter (nm) between the beginning of the growth and the period when the growth significantly slows down, and $\Delta t$ is the duration of the growth (h).

\section{Results and discussions}

\subsection{Evolution of particle number size distributions during regional new particle events}

The SMPS and MPSS were fully operational during 26 days at T0, and 22 days at T1, from 2-29 June 2010. The time series of the particle number size distributions show that new particle events frequently occurred at both sites (Fig. 1), indicating that these events occurred on a regional scale. A total

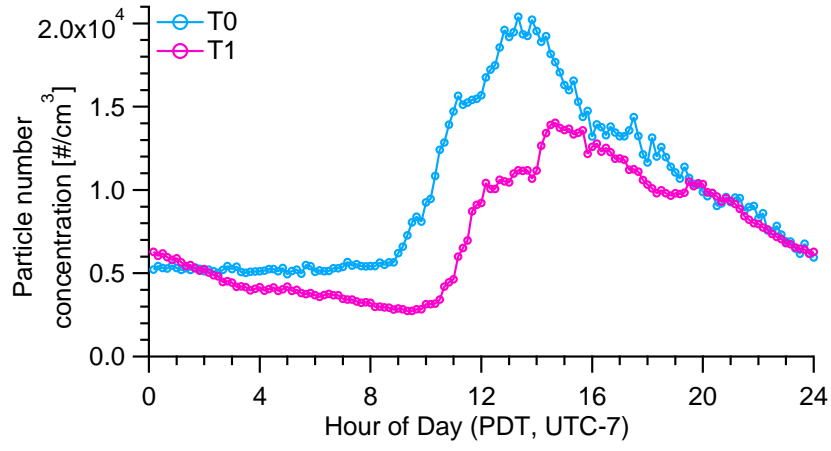

Figure 2. Diurnal patterns of particle number concentrations measured at the T0 and $\mathrm{T} 1$ sites during NPE days.

of 19 NPEs were identified at T1 ( $86 \%$ of the time; Table 1$)$, eight of which were considered as "strong" and eleven as "weak". Most of the events (14 in total) occurred during periods of southwesterly wind that transported urban plumes to the $\mathrm{T} 1$ site (i.e., $\mathrm{T} 0 \rightarrow \mathrm{T} 1$ ), except for 5 events which occurred during northwesterly wind periods (Table 1). In addition, all eight strong NPEs occurred during the $\mathrm{T} 0 \rightarrow \mathrm{T} 1$ periods (Table 1). At T0, 22 new particle events were identified, 18 of which were considered as "strong" and only four events were "weak". 
Figure 2 compares the average daily evolution patterns of particle number concentrations at the $\mathrm{T} 0$ and $\mathrm{T} 1$ sites during NPE days. Generally, the increase of the particle number concentration during these events was significantly higher at T0 than at T1 (average $9.6 \times 10^{3}$ vs. $3.8 \times 10^{3} \# \mathrm{~cm}^{-3} \mathrm{~h}^{-1}, p<0.05$ with Student's $t$ test; Table 1). The average $( \pm 1 \sigma)$ growth rate of new particles was also higher at T0 $\left(7.1 \pm 2.7 \mathrm{~nm} \mathrm{~h}^{-1}\right.$ vs. $6.2 \pm 2.5 \mathrm{~nm} \mathrm{~h}^{-1}$ at $\mathrm{T} 1$ ), but the difference was not statistically significant (i.e., $p>0.05$ with Student's $t$ test). The growth rates given in Table 1 correspond to the first hours of the observation, when the increase of the modal diameter is linear. In fact, the growth rate is usually quite linear during the first $2-3 \mathrm{~h}$ and slows down afterwards (Fig. 5a and 5c). One reason for the decrease of the growth rate after a few hours may be that when particles grow to a certain diameter, the condensation of additional species onto the surface of these particles will result in a very small increase of their sizes. The occurrence of relatively stronger NPEs at T0 is likely due to the proximity of emission sources of precursor species and a higher anthropogenic influence. Indeed, the frequency as well as the growth rates observed during the present study were much higher than those reported by Lunden et al. (2006) at $\sim 35 \mathrm{~km}$ northeast of $\mathrm{T} 1$ (frequency $=30 \%$ of the time, average growth rate $=3.8 \pm 1.9 \mathrm{~nm} \mathrm{~h}^{-1}$ ), where the lower frequency and growth rates might be related to the fact that their site was located deeper into the forest and subjected to relatively lesser anthropogenic influences from urban areas to the southwest (e.g., Sacramento and the San Francisco Bay Area). The growth rates measured during the present study are also much higher than those observed at Hyytiälä, Finland, where NPEs have been extensively observed and described over the past 15 years. Riipinen et al. (2011) report a median growth rate of $2.3 \mathrm{~nm} \mathrm{~h}^{-1}$ during the years 2003-2007, much lower than at $\mathrm{T} 1\left(6.2 \mathrm{~nm} \mathrm{~h}^{-1}\right)$ and $\mathrm{T} 0$ $\left(7.1 \mathrm{~nm} \mathrm{~h}^{-1}\right)$. NPEs at Hyytiälä are mainly driven by the photooxidation of biogenic precursors, and growth rates measured in this kind of environment depend on the concentration and volatility of the condensing material (Pierce et al., 2011; Riipinen et al., 2011; Pierce et al., 2012; Riipinen et al., 2012). The Sacramento and Sierra Foothill region, however, is influenced by both urban and biogenic emission sources. Thus, the comparison between the growth rates at these different sites suggests that the degree of anthropogenic influence may be an important factor driving the growth rate.

During the present study, all growth events began in the morning, with the appearance of an Aitken mode observed with the MPSS between 09:00 and 12:00 (PDT). Particle growth lasted several hours, with size modes reaching their maximum in the afternoon, typically after 15:00 PDT. The modal diameters at the end of the growth in general peaked between $40-50 \mathrm{~nm}$, but for several cases, the modal diameter did not reach $35 \mathrm{~nm}$, especially for the weakest events or when a change in the wind direction was observed during the day (Fig. 1).

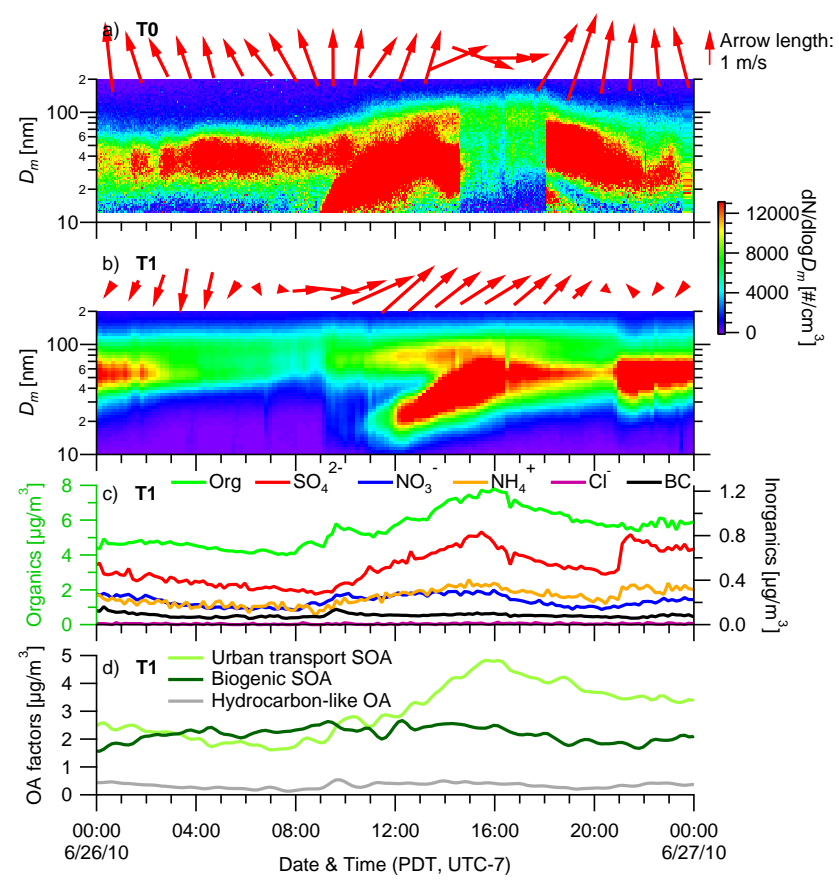

Figure 3. Comparison of the time evolution of the particle size distributions at the (a) T0 and (b) T1 sites on 26 June, along with the hourly averaged wind direction (length of the arrows is proportional to the wind speed) for each site. Time series of (c) NR-PM species $_{1}$ and BC, and (d) three different organic aerosol factors.

An important observation of the present study is that NPEs began at $\mathrm{T} 1 \mathrm{a}$ few hours later than at $\mathrm{T} 0$, especially during days characterized with daytime $\mathrm{T} 0 \rightarrow \mathrm{T} 1$ transport. A typical example of this phenomenon occurred on 26 June (Figs. 3 and 4). According to Fast et al. (2012), a T0 to T1 transport occurred that day. Particles smaller than $20 \mathrm{~nm}$ (in $D_{\mathrm{m}}$ ) began to increase slightly before 09:00 PDT at T0 (Fig. 3a), and an Aitken mode appeared at the same time (Fig. 4). Then, during the following hours, the modal diameter increased slowly up to $\sim 50 \mathrm{~nm}$ (in $D_{\mathrm{m}}$ ), likely due to condensation of lowvolatility compounds onto the surface of these new particles. The increase of the modal diameter could also be due to coagulation, but this process is expected to be very slow for particles in the Aitken mode. Thus, as shown in Fig. 3a, the evolution of the particle number size distribution shows a "banana shape", which is a typical observation for the growth of new particles. At T1, the same phenomenon occurred at $\sim$ 11:00 PDT, i.e., $2 \mathrm{~h}$ after T0 (Fig. $3 \mathrm{~b}$ ). This time delay is consistent with the wind data recorded at $\mathrm{T} 1$ which indicate the sampling of air masses transported from the T0 direction. The much lower concentrations of particles smaller than $20 \mathrm{~nm}$ between 09:00 and 11:00 PDT at T1 (Fig. 3b), compared with T0 (Fig. 3a), suggests that new particle formation occurred much near and upwind of $\mathrm{T} 0$ and not close to T1. In other words, the banana-shaped evolution pattern observed at T1 was likely independent of the emissions in the 


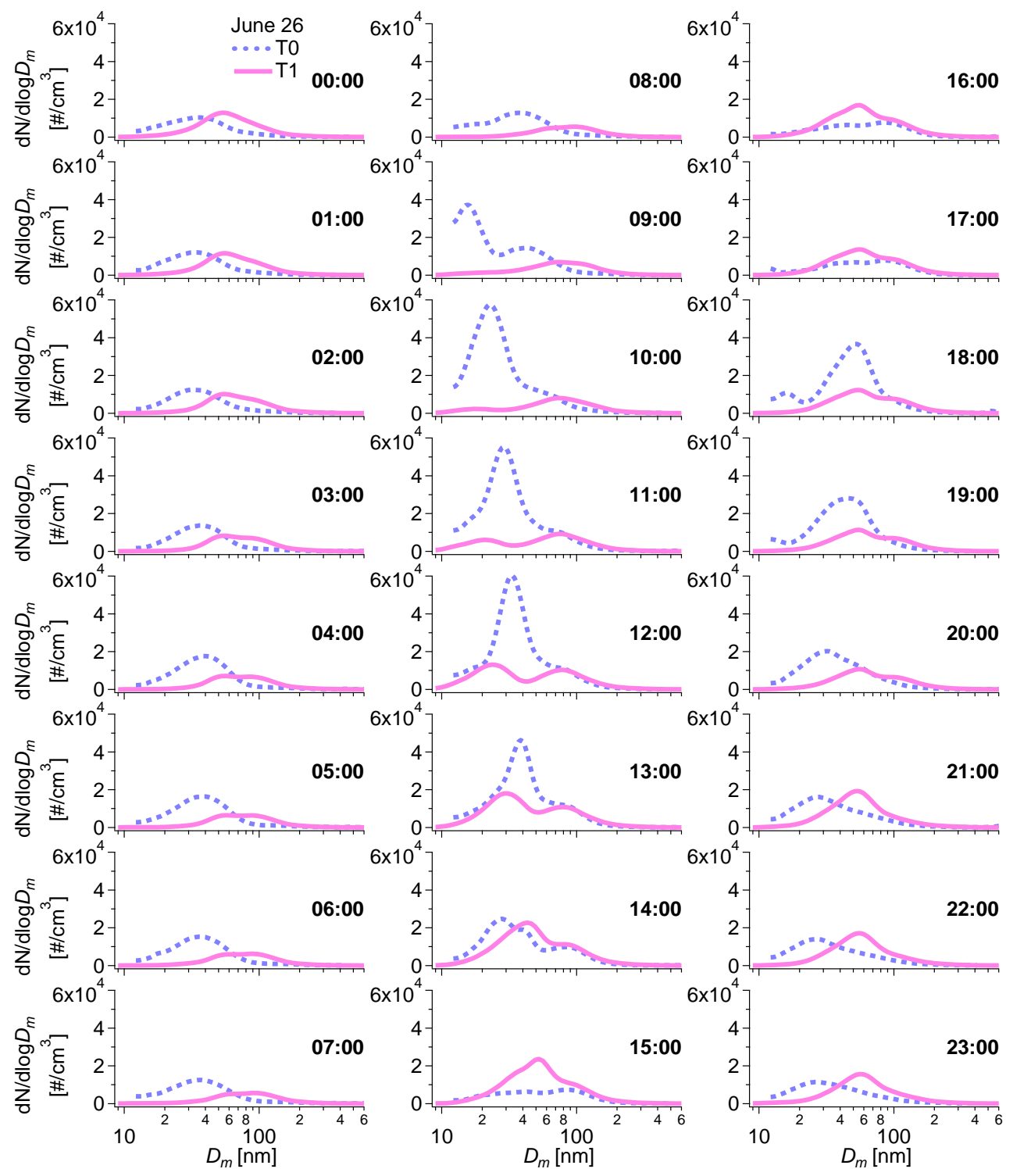

Figure 4. Comparisons of the average particle number size distributions for each hour at T0 and T1 during June 26.

$\mathrm{T} 1$ area and mostly dependent on the emissions near $\mathrm{T} 0$ and upwind of T0. Further evidence for this pseudo Lagrangian sampling is the observation of a sudden change in wind direction at $\sim 14: 30$ at $\mathrm{T} 0$ that brought in a very clean air mass associated with a sharp decrease of particle number concentration that lasted for $\sim 3.5 \mathrm{~h}$ (Fig. 3a). Particle concentration at T0 increased again at $\sim$ 18:00 PDT after a shift of the wind direction back to southwesterly. A mirrored decrease of particle concentration, although less dramatically, was observed at 16:30 at $\mathrm{T} 1, \sim 2 \mathrm{~h}$ after the clean air mass event at T0 (Fig. 3b). The increase of particle number concentration occurred at T1 around 21:00 PDT, $\sim 3 \mathrm{~h}$ after the increase occurred at $\mathrm{T} 1$, consistent with gradually decreasing wind speed from 16:30 to 21:00 PDT. The wind direction at T1 remained southwesterly during the entire afternoon (Fig. 3b).
This time delay between $\mathrm{T} 0$ and $\mathrm{T} 1$ was also observed during the other events, and this is confirmed by comparing the diurnal evolution profiles of particle number concentrations (Fig. 2) and size distributions at both sites (Fig. 5a and c). These observations indicate that new particle growth generally occurred during $\mathrm{T} 0 \rightarrow \mathrm{T} 1$ transport promoted by the daytime southwesterly wind and that the new particle growth events were generally more intense at $\mathrm{T} 0$ compared to those at T1. Wind rose plot during NPEs (Fig. 6g) confirms that these events usually occurred when the wind was coming from the southwest, which corresponds to the location of the Sacramento metropolitan area. On the other hand, when an NPE was not observed, the wind was coming mainly from the northwest and the west (Fig. 6h), bringing air masses 


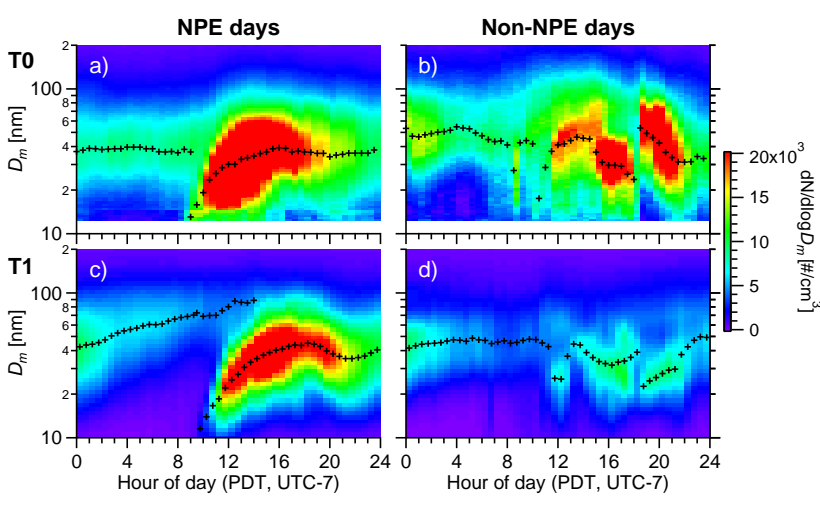

Figure 5. Diurnal size distributions of the particle number concentration at the (a, b) T0 and (c, d) T1 sites during NPE days (left panel) and non-NPE days (right panel). Black crosses correspond to the modal diameters fitted by log-normal distributions.

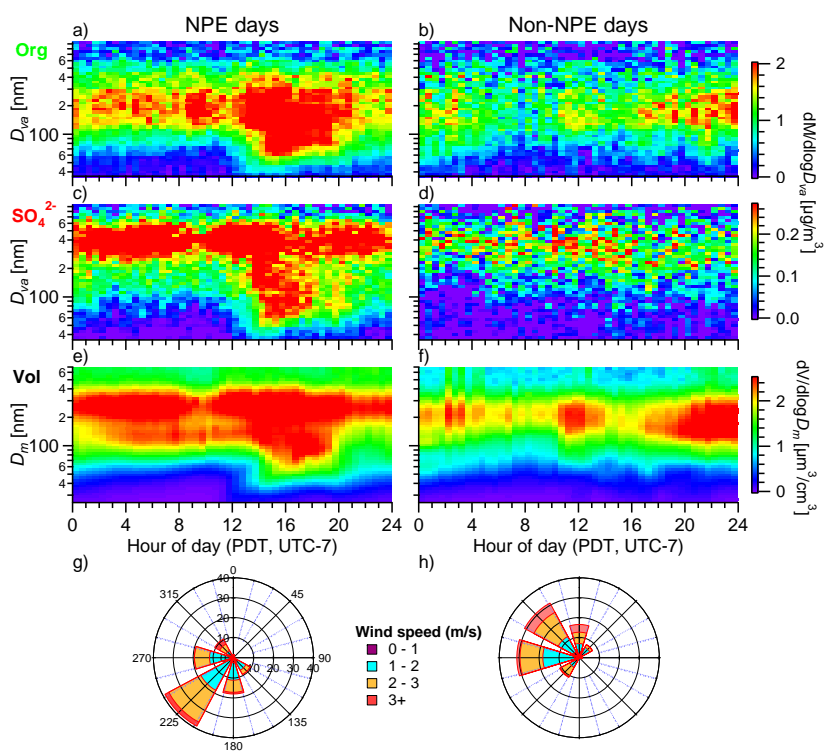

Figure 6. Diurnal size distributions of $(\mathbf{a}, \mathbf{b}) \mathrm{Org},(\mathbf{c}, \mathbf{d}) \mathrm{SO}_{4}^{2-}$, and $(\mathbf{e}, \mathbf{f})$ particle volume concentrations, and $(\mathbf{g}, \mathbf{h})$ daytime wind rose plots (08:00-20:00 PDT) for NPE days (left panel) and non-NPE days (right panel) at $\mathrm{T} 1$.

dominated by biogenic emissions (Setyan et al., 2012), thus reducing anthropogenic influences at $\mathrm{T} 1$.

It is interesting to notice that the evolution of the particle number size distributions and concentrations during the evening and the night is not similar at T0 and T1. At T0, particle number concentration remains almost constant between 23:00 and 08:00 PDT (Fig. 2), while the mode is centered at $\sim 35-40 \mathrm{~nm}$ (in $D_{\mathrm{m}}$ ) during this period (Fig. 5a). On the contrary, particle number concentration decreases gradually at T1 during night (Fig. 2), while the modal diameter increases from $35 \mathrm{~nm}$ (at 21:00 PDT) up to $70 \mathrm{~nm}$ (at 08:00 PDT the following day; Fig. $5 \mathrm{c}$ ). This may be due to the fact that the T0 site was more influenced by nanoparticles from ve- hicular emissions, due to the proximity of traffic, anthropogenic emissions, and transport from the Bay Area. On the other hand, the $\mathrm{T} 1$ site was more influenced by downslope winds during the night, when a change in the wind direction brought down more aged aerosols from the Sierra Nevada to the foothills (Setyan et al., 2012).

\subsection{Evolution of particle chemistry during new particle growth}

The evolution of particle chemistry during an NPE at T1 was studied in detail with an HR-ToF-AMS. As summarized in Table 1, the increase of particle number concentration during NPE was accompanied by an increase of organics and sulfate in ultrafine particles $\left(40-120 \mathrm{~nm}\right.$ in $\left.D_{\mathrm{va}}\right)$. The average $( \pm 1 \sigma)$ increase of organics in that size range was $0.71( \pm 0.29) \mu \mathrm{g} \mathrm{m}^{-3}$ while that of sulfate was 0.10 $( \pm 0.11) \mu \mathrm{g} \mathrm{m}^{-3}$.

Figure 6 shows the diurnal size distributions of organic matter, sulfate, and particle volume concentrations, along with the wind rose plots during NPE days and non-event days. The growth of new particles was mainly contributed by sulfate and organics (Fig. 6a and c), but the increase of particle mass was observed by the AMS after 11:00 PDT, later than the increase of number concentration according to the MPSS. This is because the smallest size measured by our MPSS is $10 \mathrm{~nm}$ (in $D_{\mathrm{m}}$ ), while the transmission through the AMS is significant only for particles larger than $30 \mathrm{~nm}$ (in $D_{\text {va }}$ ) (Jayne et al., 2000). Given that particle density at T1 was on average 1.4 during this study (Setyan et al., 2012), and assuming that they are spherical, the smallest particles measured by the AMS correspond to $\sim 21 \mathrm{~nm}$ in $D_{\mathrm{m}}$. Thus, the MPSS was the first instrument to detect the growth of new particles, while the HR-ToF-AMS observed the growth 2 or $3 \mathrm{~h}$ later, depending on the growth rate. A similar observation was reported during NPEs in Pittsburgh (Zhang et al., 2004a). It is interesting to notice that organics, sulfate, and particle volume exhibit qualitatively the same diurnal size distributions (Fig. 6). Indeed, they have a constant modal diameter in larger particles during the entire day, and they increase in ultrafine particles in the afternoon during the growth events.

The diurnal patterns of organics and sulfate in three different size ranges $\left(40-120,120-200\right.$, and $200-800 \mathrm{~nm}$ in $\left.D_{\text {va }}\right)$ show that their afternoon increase occurred mainly in ultrafine particles $(40-120 \mathrm{~nm})$ while the increases in the rest of the sizes were moderate during NPE days (Fig. 7a and c). In comparison, the diurnal profiles of both species were relatively flat and their concentrations much lower during the non-event days (Fig. 7b and d). Although both organics and sulfate in ultrafine particles increased in the afternoon, the increase of the organic mass in the $40-120 \mathrm{~nm}$ particles was on average 7 times higher than that of sulfate (see above and Fig. 8d and e). Clearly, the growth of new particles was mainly driven by organics. This is in agreement with 


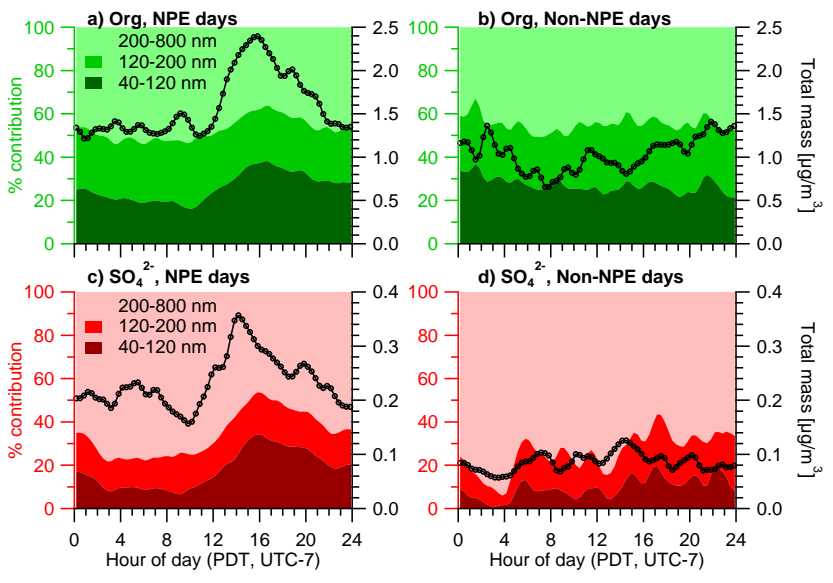

Figure 7. Diurnal patterns of the concentrations of (a, b) Org and (c, d) $\mathrm{SO}_{4}^{2-}$ (black circles and lines, right $y$-axes) and the mass fractions in the range $40-120,120-200$ and $200-800 \mathrm{~nm}$ (in $D_{\text {va }}$, left $y$-axes) during NPE days (left panel) and non-NPE days (right panel) at $\mathrm{T} 1$.

previous studies, which also emphasized the key-role of organics in the growth of new particles up to CCN sizes (Laaksonen et al., 2008; Smith et al., 2008; Ziemba et al., 2010; Zhang et al., 2011; Ahlm et al., 2012; Pierce et al., 2012; Riipinen et al., 2012).

Another important observation is the substantial increase of the signals of four nitrogen-containing ions (i.e., $\mathrm{CHN}^{+}$, $\mathrm{CH}_{4} \mathrm{~N}^{+}, \mathrm{C}_{2} \mathrm{H}_{3} \mathrm{~N}^{+}$, and $\mathrm{C}_{2} \mathrm{H}_{4} \mathrm{~N}^{+}$) in submicron particles during the new particle growth periods (Fig. 8f). On average, the concentration of these ions during NPE days was 2.4 times the concentration observed during non-NPE days (Fig. 11). Since these $\mathrm{C}_{\mathrm{x}} \mathrm{H}_{\mathrm{y}} \mathrm{N}^{+}$ions are generally related to alkylamine species (Ge et al., 2014), this class of compounds was likely involved in the growth of new particles. This is consistent with previous findings in the atmosphere (e.g., Makela et al., 2001; Smith et al., 2008, 2010; Bzdek et al., 2011; Creamean et al., 2011; Laitinen et al., 2011). Recent studies have found that sulfuric acid-amine clusters are highly stable and that even trace amount of amines (e.g., a few ppt) can enhance particle formation rates by orders of magnitude compared with ammonia (Zollner et al., 2012; Almeida et al., 2013). The importance of gas-phase amines in the generation of organic salts involved in the formation of new particles was also confirmed by thermodynamic modeling study (Barsanti et al., 2009). Based on the mass spectrometry fragmentation patterns of amine standards analyzed in our lab (Ge et al., in preparation), the average concentration of aminium $\left(R_{1} R_{2} R_{3} N^{+}\right.$, where $R_{1}, R_{2}, R_{3}$ are either $H$ or an alkyl group) is estimated to be approximately $1 / 10$ th that of ammonium at T1 during this study (Fig. 8f). Although we are unable to directly assess the importance of amines in new particle formation based on this study, our results suggest that

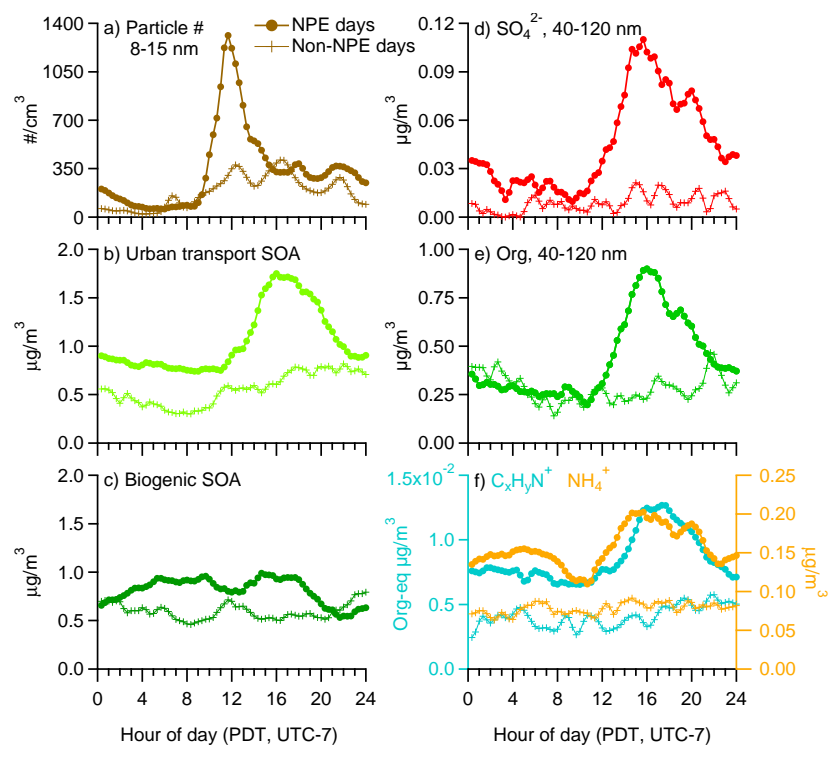

Figure 8. Diurnal patterns of (a) particle number concentration (10$15 \mathrm{~nm}$ ), (b) urban transport SOA, (c) biogenic SOA, (d) $\mathrm{SO}_{4}^{2-}$ (40$120 \mathrm{~nm}$ in $\left.D_{\text {va }}\right)$, (e) Org $\left(40-120 \mathrm{~nm}\right.$ in $\left.D_{\text {va }}\right)$, and (f) N-containing organic ions $\left(=\mathrm{CHN}^{+}+\mathrm{CH}_{4} \mathrm{~N}^{+}+\mathrm{C}_{2} \mathrm{H}_{3} \mathrm{~N}^{+}+\mathrm{C}_{2} \mathrm{H}_{4} \mathrm{~N}^{+}\right)$and ammonium during NPE (solid symbols) and non-NPE (open symbols) days at $\mathrm{T} 1$.

amines likely played an important role in the formation of new particles in the Sacramento and Sierra foothills region.

Due to the high contribution of organics to submicron aerosol mass in the region, positive matrix factorization (PMF) analysis was performed on the high resolution mass spectra of the AMS to investigate the sources and processes of organic aerosols (Setyan et al., 2012). Briefly, three distinct factors were determined, including a biogenically influenced SOA associated with the regional biogenic emissions $(\mathrm{O} / \mathrm{C}$ ratio $=0.54,40 \%$ of total organic mass $)$, an anthropogenically influenced SOA associated with transported urban plumes $(\mathrm{O} / \mathrm{C}$ ratio $=0.42,51 \%)$, and a hydrocarbon-like organic aerosol (HOA) mainly associated with local primary emissions $(\mathrm{O} / \mathrm{C}$ ratio $=0.08,9 \%)$. Details on the determination and validation of these three OA types are given in Setyan et al. (2012). It is important to clarify here that the biogenic SOA and urban transport SOA identified at T1 do not correspond to SOAs formed from $100 \%$ anthropogenic or biogenic precursors. In fact, the so-called biogenic SOA was found in air masses with dominant biogenic influence and little anthropogenic influence, while the urban transport SOA was found in air masses characterized as urban plumes mixed with the continuously present biogenic emissions in the region. These observations are consistent with radiocarbon analysis of fine particulate matter, which has shown that modern carbon worldwide often contributes $>70 \%$ of the total carbon, particularly downwind of urban areas (Glasius et al., 2011; Schichtel et al., 2008 and references therein). 

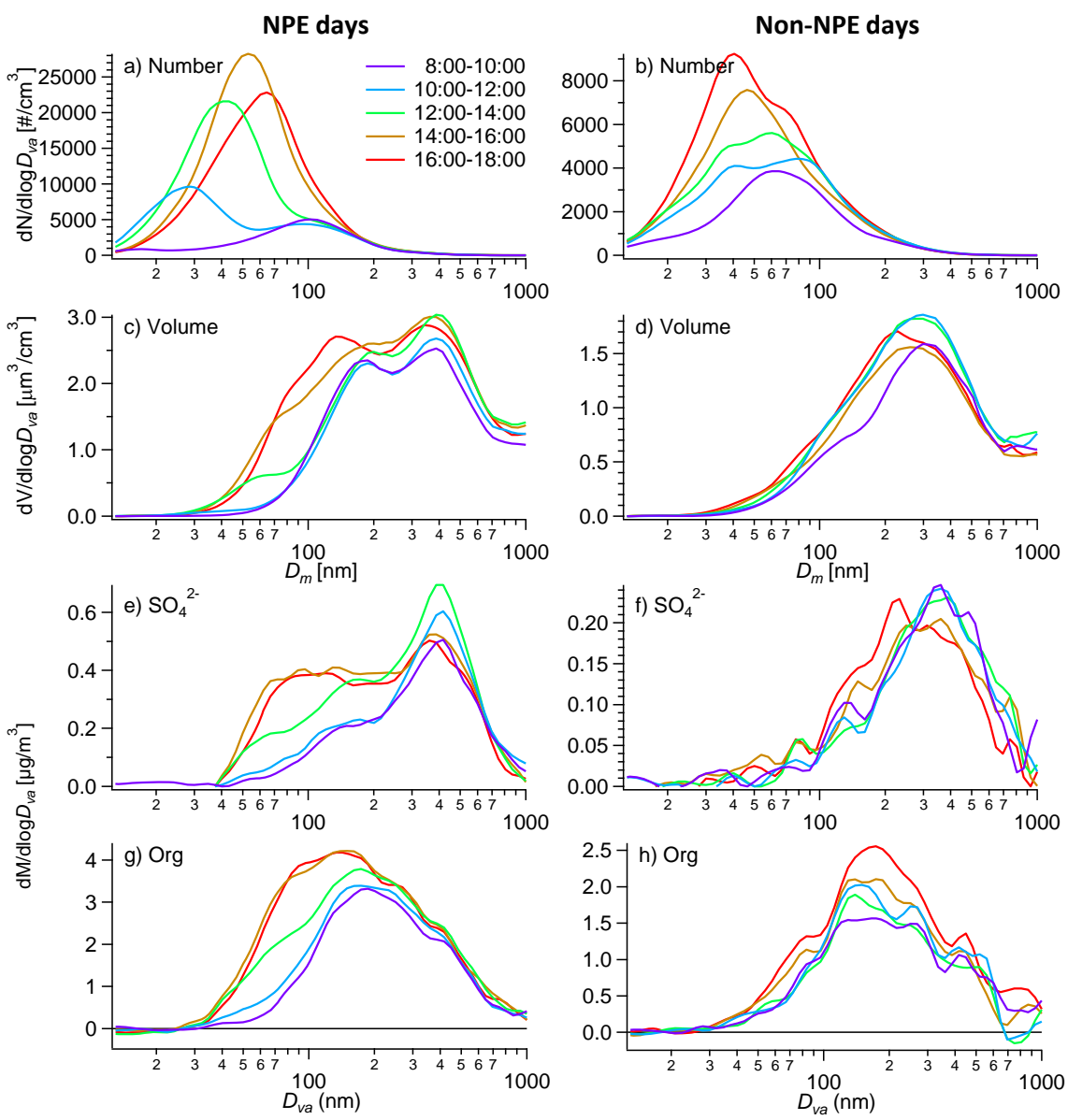

Figure 9. $2 \mathrm{~h}$ averaged size distributions of $(\mathbf{a}, \mathbf{b})$ particle number and $(\mathbf{c}, \mathbf{d})$ volume, $(\mathbf{e}, \mathbf{f}) \mathrm{SO}_{4}^{2-}$, and (g, h) Org during NPE days (left panel) and non-NPE days (right panel) between 08:00 and 18:00 PDT at T1.

As shown in Fig. 8, during NPE days, the mass concentration of urban transport SOA increased by more than a factor of 2 (from 0.75 to $1.7 \mu \mathrm{g} \mathrm{m}^{-3}$ ) between 10:00 and 16:00 PDT (Fig. 8b), whereas that of biogenic SOA increased only slightly by $\sim 10 \%$ during that period (from $0.84-0.93 \mu \mathrm{g} \mathrm{m}^{-3}$, Fig. $8 \mathrm{c}$ ). This result underlines the keyrole played by the urban plumes from Sacramento in the NPEs at Sierra foothills.

Figure 9 shows the evolutions of the mass-weighted size distributions of $\mathrm{Org}, \mathrm{SO}_{4}^{2-}$, and organic tracer ions and the particle number distributions during daytime. The average size distributions of Org and $\mathrm{SO}_{4}^{2-}$ during NPE days show significant increase of concentrations in the small mode (Fig. 9e and g). On the other hand, the increases of the concentrations of Org and $\mathrm{SO}_{4}^{2-}$ in ultrafine particles were all negligible during non-event days (Fig. 9f and h).

Another important parameter to determine was the neutralization of sulfate in the ultrafine mode during NPEs. We already know from the mass spectral mode of the AMS that sulfate was fully neutralized in the bulk during the entire study (Setyan et al., 2012). Many previous studies mentioned that sulfate involved in NPEs was usually under the form of sulfuric acid, especially during the initial steps of the growth (Brock et al., 2003; Zhang et al., 2004a; Yue et al., 2010; Bzdek et al., 2012). However, northern California contains very large agricultural regions with a lot of sources of ammonia, which could possibly neutralize sulfate in the ultrafine mode. Using high mass resolution mass spectra acquired under PToF mode, we determined the size distributions of ammonium and sulfate based on those of the $\mathrm{NH}_{3}^{+}$and $\mathrm{SO}^{+}$, which are the ions of ammonium and sulfate, respectively, with the highest signal-to-noise ratio (see supplementary material for details of this data treatment). As shown in Fig. 10, despite relatively noisy data, the size distributions suggest that sulfate was fully neutralized by ammonium in the entire size range, including ultrafine particles. Moreover, we did not observe any difference in the sulfate neutralization between NPE and non-NPE days or between different times of the day. These results indicate that sulfate in ultrafine particles was present in the form of ammonium sulfate and that sulfuric acid was quickly neutralized after condensation. 
Table 2. Summary of average value \pm 1 standard deviation for meteorological parameters, particle phase species, and gaseous species during new particle event (NPE) and non-NPE days at the T1 site between 08:00 and 18:00 PDT.

\begin{tabular}{|c|c|c|}
\hline Parameter & NPE days & Non-NPE days \\
\hline \multicolumn{3}{|c|}{ Meteorological data } \\
\hline Temperature $\left({ }^{\circ} \mathrm{C}\right)$ & $24.2 \pm 4.4$ & $25.0 \pm 4.1$ \\
\hline Relative humidity (\%) & $45.3 \pm 12.6$ & $27.1 \pm 12.1$ \\
\hline Solar radiation $\left(\mathrm{W} \mathrm{m}^{-2}\right)$ & $702.9 \pm 246.1$ & $792.7 \pm 200.4$ \\
\hline \multicolumn{3}{|c|}{ Particle phase } \\
\hline Particle number $\left(\# \mathrm{~cm}^{-3}\right)$ & $9.4 \times 10^{3} \pm 6.1 \times 10^{3}$ & $4.1 \times 10^{3} \pm 1.9 \times 10^{3}$ \\
\hline Growth rate $\left(\mathrm{nm} \mathrm{h}^{-1}\right)$ & $6.2 \pm 2.5$ & - \\
\hline Biogenic SOA $\left(\mu \mathrm{g} \mathrm{m}^{-3}\right)$ & $0.90 \pm 0.65$ & $0.56 \pm 0.27$ \\
\hline Urban transport SOA $\left(\mu \mathrm{g} \mathrm{m}^{-3}\right)$ & $1.2 \pm 0.90$ & $0.54 \pm 0.44$ \\
\hline $\mathrm{HOA}\left(\mu \mathrm{g} \mathrm{m}^{-3}\right)$ & $0.16 \pm 0.15$ & $0.11 \pm 0.08$ \\
\hline $\mathrm{SO}_{4}^{2-}\left(\mu \mathrm{g} \mathrm{m}^{-3}\right)$ & $0.39 \pm 0.22$ & $0.14 \pm 0.10$ \\
\hline $\mathrm{NO}_{3}^{-}\left(\mu \mathrm{g} \mathrm{m}^{-3}\right)$ & $0.13 \pm 0.08$ & $0.054 \pm 0.036$ \\
\hline $\mathrm{BC}\left(\mu \mathrm{g} \mathrm{m}^{-3}\right)$ & $0.042 \pm 0.028$ & $0.027 \pm 0.017$ \\
\hline \multicolumn{3}{|c|}{ Trace gases (ppb) } \\
\hline Terpenes & $0.058 \pm 0.088$ & $0.043 \pm 0.034$ \\
\hline Isoprene & $1.40 \pm 1.02$ & $1.35 \pm 0.80$ \\
\hline MACR + MVK & $0.98 \pm 0.79$ & $0.75 \pm 0.50$ \\
\hline Methanol & $6.36 \pm 3.12$ & $5.36 \pm 1.76$ \\
\hline Acetone & $1.90 \pm 1.09$ & $1.64 \pm 0.42$ \\
\hline Formaldehyde & $2.71 \pm 1.39$ & $1.83 \pm 0.81$ \\
\hline Acetaldehyde & $0.97 \pm 0.47$ & $0.71 \pm 0.24$ \\
\hline Acetic acid & $0.98 \pm 1.10$ & $0.87 \pm 0.43$ \\
\hline Acetonitrile & $0.18 \pm 0.03$ & $0.17 \pm 0.02$ \\
\hline Benzene & $0.036 \pm 0.029$ & $0.031 \pm 0.014$ \\
\hline Toluene & $0.060 \pm 0.037$ & $0.038 \pm 0.019$ \\
\hline $\mathrm{O}_{3}$ & $43.5 \pm 14.2$ & $46.2 \pm 10.5$ \\
\hline $\mathrm{NO}_{\mathrm{x}}$ & $3.8 \pm 3.3$ & $2.7 \pm 3.5$ \\
\hline $\mathrm{CO}$ & $130.1 \pm 27.0$ & $99.8 \pm 19.8$ \\
\hline
\end{tabular}

\subsection{Anthropogenic influence on new particle growth events}

The average concentrations and diurnal patterns of VOCs, trace gases $\left(\mathrm{O}_{3}, \mathrm{CO}, \mathrm{NO}_{\mathrm{x}}\right), \mathrm{BC}$, and meteorological parameters (temperature, relative humidity, and solar radiation) during NPE days and non-event days were compared (Fig. 11, Figs. S3 and S4 in the Supplement, and Table 2). An important difference between NPE and non-event days was the concentrations of photo-oxidation products (formaldehyde and acetaldehyde) and anthropogenic precursors (BC, $\mathrm{CO}$ and toluene), which were all significantly higher during NPE days than during non-event days. Photo-oxidation products were on average $\sim 50 \%$ more concentrated on NPE days (formaldehyde: $2.71 \pm 1.39 \mathrm{ppb}$ vs. $1.83 \pm 0.81 \mathrm{ppb}$ during non-NPE days; acetaldehyde: $0.97 \pm 0.47 \mathrm{ppb}$ vs. $0.71 \pm 0.24 \mathrm{ppb}$ ). The sum of methacrolein (MACR) and methyl vinyl ketone (MVK), which are the first generational products of isoprene oxidation, was also $\sim 20 \%$ higher dur- ing NPE days: $0.98 \pm 0.79 \mathrm{ppb}$ vs. $0.75 \pm 0.50 \mathrm{ppb}$. These markers of oxidation are likely correlated with other semivolatile compounds co-generated during photo-oxidation, which could condense onto the surface of particles and could be an important factor driving the growth of new particles. Moreover, the diurnal patterns of these compounds during NPE and non-NPE days show a clear difference during the afternoon, whereas the differences are much smaller during nighttime (Fig. S4 in the Supplement). This result stresses the influence of photochemistry on the formation and growth of new particles.

The average concentrations of isoprene were almost identical during NPE and non-event days (Fig. 11) but the enhancements of anthropogenic species during NPE days were more dramatic. The average concentrations of BC $\left(0.042 \pm 0.028 \mu \mathrm{g} \mathrm{m}^{-3}\right.$ during NPE days vs. $0.027 \pm 0.017 \mu \mathrm{g} \mathrm{m}^{-3}$ during non-NPE days), $\mathrm{CO}(130 \pm 27.0$ vs. $99.8 \pm 19.8 \mathrm{ppb}), \mathrm{NO}_{\mathrm{x}}(3.8 \pm 3.3$ vs. $2.7 \pm 3.5 \mathrm{ppb})$, HOA $\left(0.16 \pm 0.15\right.$ vs. $\left.0.11 \pm 0.08 \mu \mathrm{g} \mathrm{m}^{-3}\right)$, 


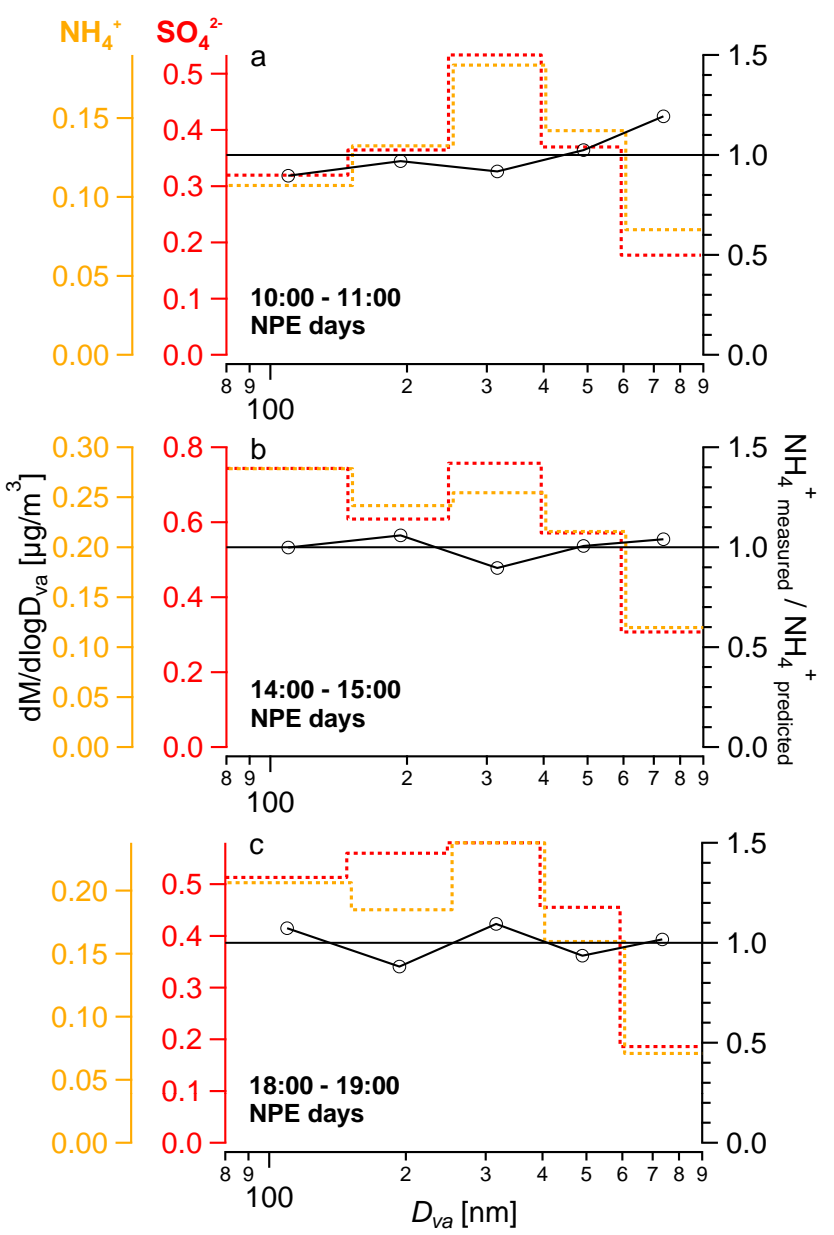

Figure 10. Size distributions of $\mathrm{SO}_{4}^{2-}, \mathrm{NH}_{4}^{+}$and the ratio of measured $\mathrm{NH}_{4}^{+}$to predicted $\mathrm{NH}_{4}^{+}\left(=2 \cdot \mathrm{SO}_{4}^{2-} \cdot 18 / 96\right)$ between (a) 10:00-11:00 PDT, (b) 14:00-15:00 PDT, and (c) 18:0019:00 PDT during NPE days at T1.

and toluene $(0.060 \pm 0.037$ vs. $0.038 \pm 0.019 \mathrm{ppb}$; Table 2$)$ were $30-60 \%$ higher on NPE days. According to the Student's $t$ test, the difference between NPE and non-NPE days was significant (i.e., $p<0.05$ ) for all the anthropogenic species, except for $\mathrm{NO}_{\mathrm{x}}$. The ozone concentrations, however, were very similar between two types of days $(46.2 \pm 10.5 \mathrm{ppb}$ during non-NPE vs. $43.5 \pm 14.2 \mathrm{ppb})$. These results point out the importance of the anthropogenic influence on the formation and growth of new particles. However, during a study undertaken at the Blodgett Forest Research Station, which is located $\sim 35 \mathrm{~km}$ on the northeast of the present sampling site and $\sim 75 \mathrm{~km}$ downwind from Sacramento, Lunden et al. (2006) observed new particle growth events when the degree of anthropogenic influence was significantly reduced.

The relative humidity $(\mathrm{RH})$ was higher on NPE days $(45 \pm 13 \%)$ compared to non-NPE days $(27 \pm 12 \%)$. Similarly, Lunden et al. (2006) and Charron et al. (2007) ob- served much higher RH during NPEs days than non-NPE days. However, most of the previous studies reported NPEs when the RH was low (Boy and Kulmala, 2002; Hamed et al., 2007, 2011; Jeong et al., 2010; Guo et al., 2012). The exact role of RH in NPEs is not clearly elucidated yet. According to Hamed et al. (2011), the anti-correlation between RH and NPEs would simply be due to the fact that solar radiation and photochemistry usually peak at noon when the RH exhibits its lower value. However, in our case, this does not seem to explain the different behavior of RH between NPE and non-NPE days, since the weather was sunny during the entire field campaign. A possible reason is that the RH was much lower during northwesterly wind periods (Setyan et al., 2012), during which we usually did not observe NPEs.

Figure 12 shows the average size-resolved mass spectra of organics in 40-120 nm $\left(D_{\mathrm{va}}\right)$ particles during NPE days and non-event days, along with the mass spectra of biogenic SOA and urban transport SOA reported in Setyan et al. (2012). The average mass spectrum of organics before the growth (i.e., between 08:00 and 10:00 PDT) was subtracted in order to remove the influence of particles existing before the start of the growth events. Therefore, the spectra shown in Fig. 12 are the average mass spectra of organic matter that contributed to the growth of $40-120 \mathrm{~nm}$ particles between 10:00-16:00 PDT during NPE days $\left(\triangle \mathrm{Org}_{40-120 \mathrm{~nm}}^{\mathrm{NPE}}\right)$ and during non-event days $\left(\triangle \mathrm{Org}_{40-120 \mathrm{~nm}}^{\text {non-NPE}}\right)$, respectively. As shown in Fig. 12a, the spectrum of $\Delta \mathrm{Org}_{40-120 \mathrm{~nm}}^{\mathrm{NPE}}$ is dominated by the signal at $m / z=44\left(\right.$ mostly $\mathrm{CO}_{2}^{+}$), while that of $m / z=43$ (mostly $\mathrm{C}_{2} \mathrm{H}_{3} \mathrm{O}^{+}$) is approximately the half of it. The spectrum of $\Delta \mathrm{Org}_{40-120 \mathrm{~nm}}^{\mathrm{NPE}}$ is very similar to that of urban transport SOA ( $r^{2}=0.95$; Fig. 12b) but its correlation coefficient towards the spectrum of biogenic SOA is lower $\left(r^{2}=0.87\right)$. On the other hand, the spectrum of $\triangle \mathrm{Org}_{40-120 \mathrm{~nm}}^{\text {non-NPE }}$ is very similar to that of biogenic SOA, as shown by the scatterplot of Fig. 12d. We further performed multilinear regression analyses to represent the mass spectra of $\Delta \mathrm{Org}_{40-120 \mathrm{~nm}}^{\mathrm{NPE}}$ and $\Delta \mathrm{Org}_{40-120 \mathrm{~nm}}^{\text {non-NPE }}$, respectively, as the linear combinations of the spectra of urban transport SOA and biogenic SOA. Based on this analysis, we estimated that during NPE days, $\sim 74 \%$ of the organic mass that contributed to the growth of ultrafine particles was SOA formed in urban transport plumes. During non-event days, the growth of ultrafine mode organics, which was much slower compared during NPE, was primarily ( $\sim 76 \%$ by mass) due to SOA influenced by regional biogenic emissions.

These results, coupled to the higher concentrations of anthropogenic compounds on NPE days suggest that the growth of new particles in the Sierra Nevada foothills was mainly driven by anthropogenic precursors transported from Sacramento and that the growth was likely promoted by the interaction between urban plumes and biogenic emissions. These observations may have important implications for our understanding of SOA formation. For example, models used to assess global SOA budget tend to underpredict the SOA 


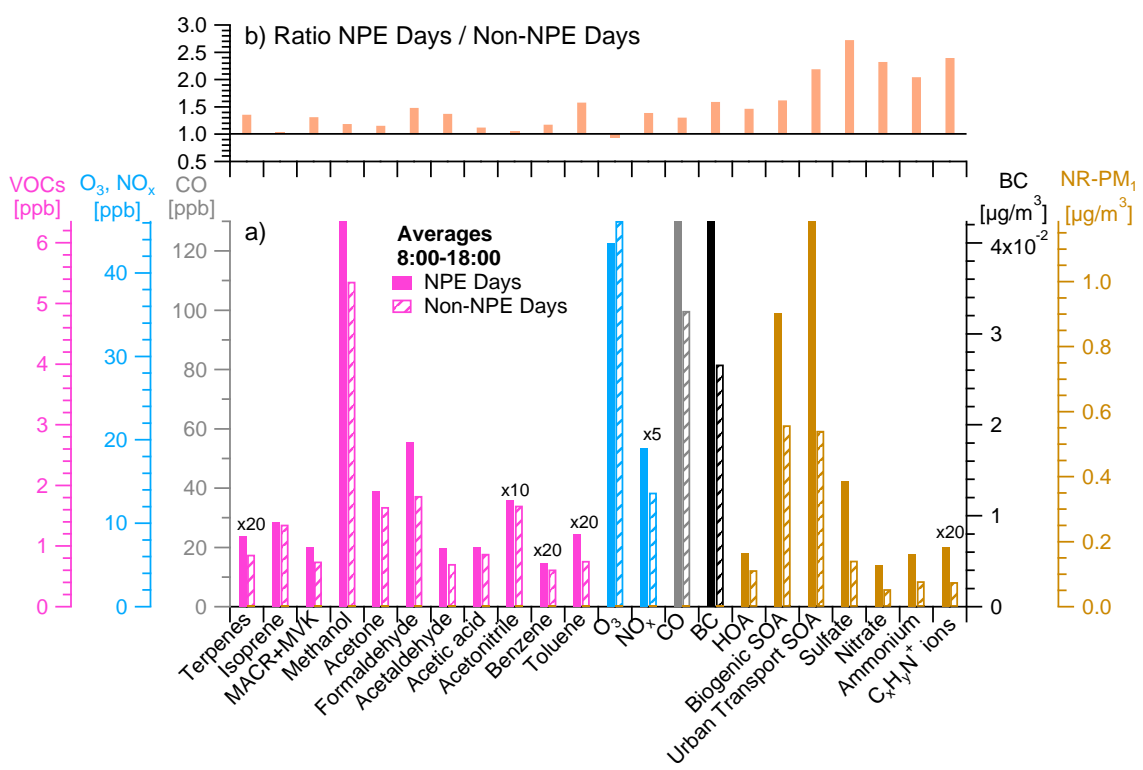

Figure 11. (a) Average concentrations of VOCs, $\mathrm{O}_{3}, \mathrm{NO}_{\mathrm{x}}, \mathrm{CO}, \mathrm{BC}$, NR-PM $\mathrm{M}_{1}$ species, different factors, and N-containing organic ions (= $\mathrm{CHN}^{+}+\mathrm{CH}_{4} \mathrm{~N}^{+}+\mathrm{C}_{2} \mathrm{H}_{3} \mathrm{~N}^{+}+\mathrm{C}_{2} \mathrm{H}_{4} \mathrm{~N}^{+}$) between 08:00 and 18:00 PDT during NPE and non-NPE days at T1. (b) NPE days / non-NPE days ratios for the same parameters.
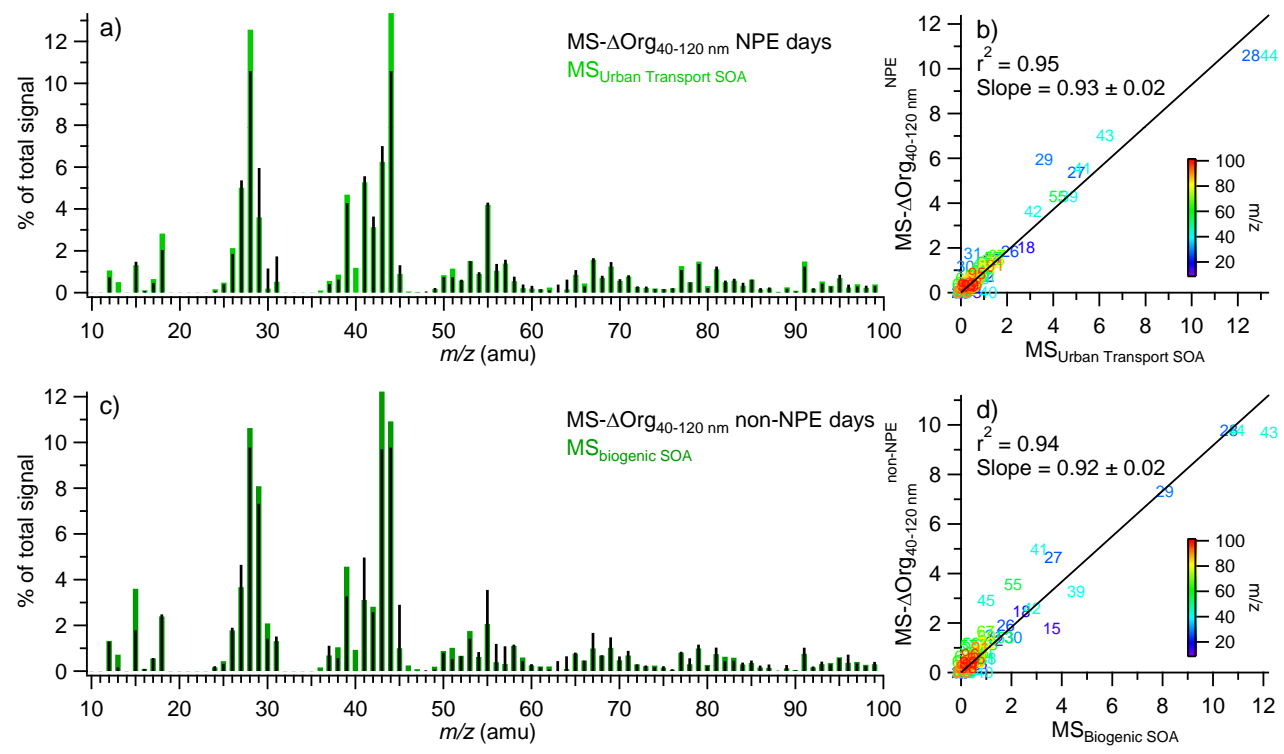

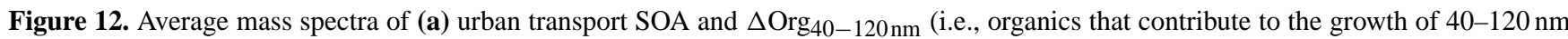

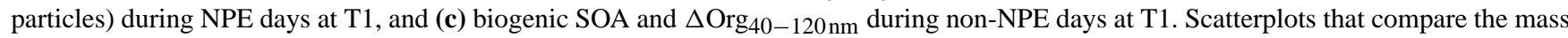
spectra of (b) urban transport SOA vs. $\Delta \mathrm{Org}_{40-120 \mathrm{~nm}}$ during NPE days, and (d) biogenic SOA vs. $\Delta$ Org $_{40-120 \mathrm{~nm}}$ during non-NPE days. The data fitting of these two scatterplots was performed using the orthogonal distance regression (ODR).

concentrations. However, in a recent study, Spracklen et al. (2011) used a model to estimate the global OA source, and compared their results with worldwide AMS observations. When they took into account anthropogenically controlled biogenic SOA formation in their estimation of the global OA budget, it considerably reduced the bias between their model and AMS observations.

\section{Conclusions}

New particle growth events were frequently observed during the US DOE's CARES campaign in northern California in June 2010. Presented here is a description of these events observed with two MPSSs deployed at Sacramento (T0, urban site) and Cool (T1, rural site at the Sierra foothills). 
Our results showed that these growth events took place on a regional scale, predominantly during periods of southwestern flow that transports urban plumes and anthropogenic emissions from the Sacramento metropolitan area and the San Francisco Bay Area near Carquinez Strait. Growth rates were on average higher at $\mathrm{T} 0\left(7.1 \pm 2.7 \mathrm{~nm} \mathrm{~h}^{-1}\right)$ than at $\mathrm{T} 1$ $\left(6.2 \pm 2.5 \mathrm{~nm} \mathrm{~h}^{-1}\right)$, but the difference is not statistically significant. The evolution of the size-resolved chemical composition of these newly formed particles has been investigated in detail with a HR-ToF-AMS deployed at T1. Our results indicate that the new particle growth was mainly driven by organics, with a small contribution of ammonium sulfate. For example, the average increase of the organic mass in ultrafine particles (40-120 nm in $D_{\text {va }}$, which corresponds to 30 $85 \mathrm{~nm}$ in Stokes (volume equivalent) diameter, assuming no internal voids, sphericity $=1$, and density $=1.4 \mathrm{~g} \mathrm{~cm}^{-3}$ ) was $0.71 \mu \mathrm{g} \mathrm{m}^{-3}$ during this period, approximately 7 times higher than that of sulfate $\left(0.10 \mu \mathrm{g} \mathrm{m}^{-3}\right)$. Our results also indicate that amines were enhanced significantly during the new particle growth, suggesting that this class of compounds likely played a role. The mass spectra of organics that contributed to the growth of ultrafine particles during the growth periods of NPE days were very similar to the mass spectrum of anthropogenically influenced SOA from urban plume. In addition, during the NPE days, the concentrations of photo-oxidation products (formaldehyde, acetaldehyde, sum of methacrolein and methyl vinyl ketone) and species representative of urban emissions (e.g., $\mathrm{BC}, \mathrm{CO}, \mathrm{NO}_{\mathrm{x}}, \mathrm{HOA}$, and toluene) were on average $50 \%$ higher than during nonevent days. These results suggest that the new particle growth events were mainly driven by the transported urban plumes and that the growth of new particles was enhanced by the interactions between biogenic emissions and transported urban plumes.

\section{The Supplement related to this article is available online at doi:10.5194/acp-14-6477-2014-supplement.}

Acknowledgements. This research was supported by the US Department of Energy (DOE), the Office of Science (BER), Atmospheric System Research Program, grant No. DE-FG02-11 ER65293, the California Air Resources Board (CARB), Agreement No. 10-305, and the California Agricultural Experiment Station, Project CA-DETX-2102-H.

Edited by: J. Thornton

\section{References}

Ahlm, L., Liu, S., Day, D. A., Russell, L. M., Weber, R., Gentner, D. R., Goldstein, A. H., DiGangi, J. P., Henry, S. B., Keutsch, F. N., VandenBoer, T. C., Markovic, M. Z., Murphy, J. G., Ren, $\mathrm{X}$., and Scheller, S.: Formation and growth of ultrafine particles from secondary sources in Bakersfield, California, J. Geophys. Res., 117, D00V08, doi:10.1029/2011JD017144, 2012.

Allan, J. D., Alfarra, M. R., Bower, K. N., Coe, H., Jayne, J. T., Worsnop, D. R., Aalto, P. P., Kulmala, M., Hyotylainen, T., Cavalli, F., and Laaksonen, A.: Size and composition measurements of background aerosol and new particle growth in a Finnish forest during QUEST 2 using an Aerodyne Aerosol Mass Spectrometer, Atmos. Chem. Phys., 6, 315-327, doi:10.5194/acp-6-315-2006, 2006.

Almeida, J., Schobesberger, S., Kurten, A., Ortega, I. K., Kupiainen-Maatta, O., Praplan, A. P., Adamov, A., Amorim, A., Bianchi, F., Breitenlechner, M., David, A., Dommen, J., Donahue, N. M., Downard, A., Dunne, E., Duplissy, J., Ehrhart, S., Flagan, R. C., Franchin, A., Guida, R., Hakala, J., Hansel, A., Heinritzi, M., Henschel, H., Jokinen, T., Junninen, H., Kajos, M., Kangasluoma, J., Keskinen, H., Kupc, A., Kurten, T., Kvashin, A. N., Laaksonen, A., Lehtipalo, K., Leiminger, M., Leppa, J., Loukonen, V., Makhmutov, V., Mathot, S., McGrath, M. J., Nieminen, T., Olenius, T., Onnela, A., Petaja, T., Riccobono, F., Riipinen, I., Rissanen, M., Rondo, L., Ruuskanen, T., Santos, F. D., Sarnela, N., Schallhart, S., Schnitzhofer, R., Seinfeld, J. H., Simon, M., Sipila, M., Stozhkov, Y., Stratmann, F., Tome, A., Trostl, J., Tsagkogeorgas, G., Vaattovaara, P., Viisanen, Y., Virtanen, A., Vrtala, A., Wagner, P. E., Weingartner, E., Wex, H., Williamson, C., Wimmer, D., Ye, P. L., Yli-Juuti, T., Carslaw, K. S., Kulmala, M., Curtius, J., Baltensperger, U., Worsnop, D. R., Vehkamaki, H., and Kirkby, J.: Molecular understanding of sulphuric acid-amine particle nucleation in the atmosphere, Nature, 502, 359-363, doi:10.1038/nature12663, 2013.

Asmi, E., Frey, A., Virkkula, A., Ehn, M., Manninen, H. E., Timonen, H., Tolonen-Kivimaki, O., Aurela, M., Hillamo, R., and Kulmala, M.: Hygroscopicity and chemical composition of Antarctic sub-micrometre aerosol particles and observations of new particle formation, Atmos. Chem. Phys., 10, 4253-4271, doi:10.5194/acp-10-4253-2010, 2010.

Barsanti, K. C., McMurry, P. H., and Smith, J. N.: The potential contribution of organic salts to new particle growth, Atmos. Chem. Phys., 9, 2949-2957, doi:10.5194/acp-9-2949-2009, 2009.

Boy, M. and Kulmala, M.: Nucleation events in the continental boundary layer: Influence of physical and meteorological parameters, Atmos. Chem. Phys., 2, 1-16, doi:10.5194/acp-2-1-2002, 2002.

Brock, C. A., Trainer, M., Ryerson, T. B., Neuman, J. A., Parrish, D. D., Holloway, J. S., Nicks, D. K., Jr., Frost, G. J., Hübler, G., Fehsenfeld, F. C., Wilson, J. C., Reeves, J. M., Lafleur, B. G., Hilbert, H., Atlas, E. L., Donnelly, S. G., Schauffler, S. M., Stroud, V. R., and Wiedinmyer, C.: Particle growth in urban and industrial plumes in Texas, J. Geophys. Res., 108, 4111, doi:10.1029/2002jd002746, 2003.

Bzdek, B. R., and Johnston, M. V.: New Particle Formation and Growth in the Troposphere, Anal. Chem., 82, 7871-7878, doi:10.1021/ac100856j, 2010.

Bzdek, B. R., Zordan, C. A., Luther, G. W., and Johnston, M. V.: Nanoparticle Chemical Composition During New 
Particle Formation, Aerosol Sci. Technol., 45, 1041-1048, doi:10.1080/02786826.2011.580392, 2011.

Bzdek, B. R., Zordan, C. A., Pennington, M. R., Luther, G. W., and Johnston, M. V.: Quantitative Assessment of the Sulfuric Acid Contribution to New Particle Growth, Environ. Sci. Technol., 46, 4365-4373, doi:10.1021/es204556c, 2012.

Canagaratna, M. R., Jayne, J. T., Jimenez, J. L., Allan, J. D., Alfarra, M. R., Zhang, Q., Onasch, T. B., Drewnick, F., Coe, H., Middlebrook, A., Delia, A., Williams, L. R., Trimborn, A. M., Northway, M. J., DeCarlo, P. F., Kolb, C. E., Davidovits, P., and Worsnop, D. R.: Chemical and microphysical characterization of ambient aerosols with the aerodyne aerosol mass spectrometer, Mass Spectrom. Rev., 26, 185-222, doi:10.1002/mas.20115, 2007.

Charron, A., Birmili, W., and Harrison, R. M.: Factors influencing new particle formation at the rural site, Harwell, United Kingdom, J. Geophys. Res., 112, D14210, doi:10.1029/2007JD008425, 2007.

Creamean, J. M., Ault, A. P., Ten Hoeve, J. E., Jacobson, M. Z., Roberts, G. C., and Prather, K. A.: Measurements of Aerosol Chemistry during New Particle Formation Events at a Remote Rural Mountain Site, Environ. Sci. Technol., 45, 8208-8216, doi:10.1021/es103692f, 2011.

DeCarlo, P. F., Kimmel, J. R., Trimborn, A., Northway, M. J., Jayne, J. T., Aiken, A. C., Gonin, M., Fuhrer, K., Horvath, T., Docherty, K. S., Worsnop, D. R., and Jimenez, J. L.: Field-deployable, high-resolution, time-of-flight aerosol mass spectrometer, Anal. Chem., 78, 8281-8289, doi:10.1021/ac061249n, 2006.

de Gouw, J. A., Middlebrook, A. M., Warneke, C., Goldan, P. D., Kuster, W. C., Roberts, J. M., Fehsenfeld, F. C., Worsnop, D. R., Canagaratna, M. R., Pszenny, A. A. P., Keene, W. C., Marchewka, M., Bertman, S. B., and Bates, T. S.: Budget of organic carbon in a polluted atmosphere: Results from the New England Air Quality Study in 2002, J. Geophys. Res.-Atmos., 110, D16305, doi:10.1029/2004JD005623, 2005.

Dillon, M. B., Lamanna, M. S., Schade, G. W., Goldstein, A. H., and Cohen, R. C.: Chemical evolution of the Sacramento urban plume: Transport and oxidation, J. Geophys. Res.-Atmos., 107, 4045, doi:10.1029/2001jd000969, 2002.

Dunn, M. J., Jiménez, J.-L., Baumgardner, D., Castro, T., McMurry, P. H., and Smith, J. N.: Measurements of Mexico City nanoparticle size distributions: Observations of new particle formation and growth, Geophys. Res. Lett., 31, L10102, doi:10.1029/2004g1019483, 2004.

Fast, J. D., Gustafson Jr, W. I., Berg, L. K., Shaw, W. J., Pekour, M., Shrivastava, M., Barnard, J. C., Ferrare, R. A., Hostetler, C. A., Hair, J. A., Erickson, M., Jobson, B. T., Flowers, B., Dubey, M. K., Springston, S., Pierce, R. B., Dolislager, L., Pederson, J., and Zaveri, R. A.: Transport and mixing patterns over Central California during the carbonaceous aerosol and radiative effects study (CARES), Atmos. Chem. Phys., 12, 1759-1783, doi:10.5194/acp-12-1759-2012, 2012.

Ge, X., Shaw, S. L., and Zhang, Q.: Toward Understanding Amines and Their Degradation Products from Postcombustion CO2 Capture Processes with Aerosol Mass Spectrometry, Environ. Sci. Technol., 48, 5066-5075, doi:10.1021/es4056966, 2014.

Glasius, M., la Cour, A., and Lohse, C.: Fossil and nonfossil carbon in fine particulate matter: A study of five European cities, J. Geo- phys. Res.-Atmos., 116, D11302, doi:10.1029/2011jd015646, 2011.

Guo, H., Wang, D. W., Cheung, K., Ling, Z. H., Chan, C. K., and Yao, X. H.: Observation of aerosol size distribution and new particle formation at a mountain site in subtropical Hong Kong, Atmos. Chem. Phys., 12, 9923-9939, doi:10.5194/acp-12-99232012, 2012.

Hamed, A., Joutsensaari, J., Mikkonen, S., Sogacheva, L., Dal Maso, M., Kulmala, M., Cavalli, F., Fuzzi, S., Facchini, M. C., Decesari, S., Mircea, M., Lehtinen, K. E. J., and Laaksonen, A.: Nucleation and growth of new particles in Po Valley, Italy, Atmos. Chem. Phys., 7, 355-376, doi:10.5194/acp-7-355-2007, 2007.

Hamed, A., Korhonen, H., Sihto, S. L., Joutsensaari, J., Jarvinen, H., Petaja, T., Arnold, F., Nieminen, T., Kulmala, M., Smith, J. N., Lehtinen, K. E. J., and Laaksonen, A.: The role of relative humidity in continental new particle formation, J. Geophys. Res.Atmos., 116, D03202, doi:10.1029/2010jd014186, 2011.

Han, Y., Iwamoto, Y., Nakayama, T., Kawamura, K., Hussein, T., and Mochida, M.: Observation of new particle formation over a mid-latitude forest facing the North Pacific, Atmos. Environ., 64, 77-84, doi:10.1016/j.atmosenv.2012.09.036, 2013.

Jayne, J. T., Leard, D. C., Zhang, X. F., Davidovits, P., Smith, K. A., Kolb, C. E., and Worsnop, D. R.: Development of an aerosol mass spectrometer for size and composition analysis of submicron particles, Aerosol Sci. Technol., 33, 49-70, doi:10.1080/027868200410840, 2000.

Jeong, C. H., Evans, G. J., McGuire, M. L., Chang, R. Y. W., Abbatt, J. P. D., Zeromskiene, K., Mozurkewich, M., Li, S. M., and Leaitch, A. R.: Particle formation and growth at five rural and urban sites, Atmos. Chem. Phys., 10, 7979-7995, doi:10.5194/acp10-7979-2010, 2010.

Jimenez, J. L., Canagaratna, M. R., Donahue, N. M., Prevot, A. S. H., Zhang, Q., Kroll, J. H., DeCarlo, P. F., Allan, J. D., Coe, H., Ng, N. L., Aiken, A. C., Docherty, K. S., Ulbrich, I. M., Grieshop, A. P., Robinson, A. L., Duplissy, J., Smith, J. D., Wilson, K. R., Lanz, V. A., Hueglin, C., Sun, Y. L., Tian, J., Laaksonen, A., Raatikainen, T., Rautiainen, J., Vaattovaara, P., Ehn, M., Kulmala, M., Tomlinson, J. M., Collins, D. R., Cubison, M J., Dunlea, E. J., Huffman, J. A., Onasch, T. B., Alfarra, M. R., Williams, P. I., Bower, K., Kondo, Y., Schneider, J., Drewnick, F., Borrmann, S., Weimer, S., Demerjian, K., Salcedo, D., Cottrell, L., Griffin, R., Takami, A., Miyoshi, T., Hatakeyama, S., Shimono, A., Sun, J. Y., Zhang, Y. M., Dzepina, K., Kimmel, J. R., Sueper, D., Jayne, J. T., Herndon, S. C., Trimborn, A. M., Williams, L. R., Wood, E. C., Middlebrook, A. M., Kolb, C. E., Baltensperger, U., and Worsnop, D. R.: Evolution of Organic Aerosols in the Atmosphere, Science, 326, 1525-1529, 10.1126/science.1180353, 2009.

Jokinen, T., Sipilä, M., Junninen, H., Ehn, M., Lönn, G., Hakala, J., Petäjä, T., Mauldin Iii, R. L., Kulmala, M., and Worsnop, D. R.: Atmospheric sulphuric acid and neutral cluster measurements using CI-APi-TOF, Atmos. Chem. Phys., 12, 4117-4125, doi:10.5194/acp-12-4117-2012, 2012.

Kerminen, V. M., Paramonov, M., Anttila, T., Riipinen, I., Fountoukis, C., Korhonen, H., Asmi, E., Laakso, L., Lihavainen, H., Swietlicki, E., Svenningsson, B., Asmi, A., Pandis, S. N., Kulmala, M., and Petäjä, T.: Cloud condensation nuclei production associated with atmospheric nucleation: a synthesis based on ex- 
isting literature and new results, Atmos. Chem. Phys., 12, 1203712059, doi:10.5194/acp-12-12037-2012, 2012.

Kleinman, L. I., Springston, S. R., Daum, P. H., Lee, Y. N., Nunnermacker, L. J., Senum, G. I., Wang, J., Weinstein-Lloyd, J., Alexander, M. L., Hubbe, J., Ortega, J., Canagaratna, M. R., and Jayne, J.: The time evolution of aerosol composition over the Mexico City plateau, Atmos. Chem. Phys., 8, 1559-1575, doi:10.5194/acp-8-1559-2008, 2008.

Komppula, M., Lihavainen, H., Hatakka, J., Paatero, J., Aalto, P., Kulmala, M., and Viisanen, Y.: Observations of new particle formation and size distributions at two different heights and surroundings in subarctic area in northern Finland, J. Geophys. Res., 108, 4295, doi:10.1029/2002JD002939, 2003.

Koponen, I. K., Virkkula, A., Hillamo, R., Kerminen, V.-M., and Kulmala, M.: Number size distributions and concentrations of the continental summer aerosols in Queen Maud Land, Antarctica, J. Geophys. Res., 108, 4587, doi:10.1029/2003jd003614, 2003.

Kulmala, M., Kontkanen, J., Junninen, H., Lehtipalo, K., Manninen, H. E., Nieminen, T., Petäjä, T., Sipilä, M., Schobesberger, S., Rantala, P., Franchin, A., Jokinen, T., Järvinen, E., Äijälä, M., Kangasluoma, J., Hakala, J., Aalto, P. P., Paasonen, P., Mikkilä, J., Vanhanen, J., Aalto, J., Hakola, H., Makkonen, U., Ruuskanen, T., Mauldin, R. L., Duplissy, J., Vehkamäki, H., Bäck, J., Kortelainen, A., Riipinen, I., Kurtén, T., Johnston, M. V., Smith, J. N., Ehn, M., Mentel, T. F., Lehtinen, K. E. J., Laaksonen, A., Kerminen, V.-M., and Worsnop, D. R.: Direct Observations of Atmospheric Aerosol Nucleation, Science, 339, $943-$ 946, doi:10.1126/science.1227385, 2013.

Laaksonen, A., Kulmala, M., O’Dowd, C. D., Joutsensaari, J., Vaattovaara, P., Mikkonen, S., Lehtinen, K. E. J., Sogacheva, L., Dal Maso, M., Aalto, P., Petaja, T., Sogachev, A., Yoon, Y. J., Lihavainen, H., Nilsson, D., Facchini, M. C., Cavalli, F., Fuzzi, S., Hoffmann, T., Arnold, F., Hanke, M., Sellegri, K., Umann, B., Junkermann, W., Coe, H., Allan, J. D., Alfarra, M. R., Worsnop, D. R., Riekkola, M. L., Hyotylainen, T., and Viisanen, Y.: The role of VOC oxidation products in continental new particle formation, Atmos. Chem. Phys., 8, 2657-2665, doi:10.5194/acp-82657-2008, 2008.

Laitinen, T., Ehn, M., Junninen, H., Ruiz-Jimenez, J., Parshintsev, J., Hartonen, K., Riekkola, M. L., Worsnop, D. R., and Kulmala, M.: Characterization of organic compounds in 10-to 50-nm aerosol particles in boreal forest with laser desorption-ionization aerosol mass spectrometer and comparison with other techniques, Atmos. Environ., 45, 3711-3719, doi:10.1016/j.atmosenv.2011.04.023, 2011.

Lehtipalo, K., Sipilä, M., Junninen, H., Ehn, M., Berndt, T., Kajos, M. K., Worsnop, D. R., Petäjä, T., and Kulmala, M.: Observations of Nano-CN in the Nocturnal Boreal Forest, Aerosol Sci. Technol., 45, 499-509, doi:10.1080/02786826.2010.547537, 2011.

Liu, S., Hu, M., Wu, Z., Wehner, B., Wiedensohler, A., and Cheng, Y.: Aerosol number size distribution and new particle formation at a rural/coastal site in Pearl River Delta (PRD) of China, Atmos. Environ., 42, 6275-6283, doi:10.1016/j.atmosenv.2008.01.063, 2008.

Lunden, M. M., Black, D. R., McKay, M., Revzan, K. L., Goldstein, A. H., and Brown, N. J.: Characteristics of fine particle growth events observed above a forested ecosystem in the Sierra Nevada Mountains of California, Aerosol Sci. Technol., 40, 373388, doi:10.1080/02786820600631896, 2006.
Makela, J. M., Yli-Koivisto, S., Hiltunen, V., Seidl, W., Swietlicki, E., Teinila, K., Sillanpaa, M., Koponen, I. K., Paatero, J., Rosman, K., and Hameri, K.: Chemical composition of aerosol during particle formation events in boreal forest, Tellus B - Chem. Phys. Meteorol., 53, 380-393, doi:10.1034/j.16000889.2001.530405.x, 2001.

Modini, R. L., Ristovski, Z. D., Johnson, G. R., He, C., Surawski, N., Morawska, L., Suni, T., and Kulmala, M.: New particle formation and growth at a remote, sub-tropical coastal location, Atmos. Chem. Phys., 9, 7607-7621, doi:10.5194/acp-9-7607-2009, 2009.

O’Dowd, C. D., Jimenez, J. L., Bahreini, R., Flagan, R. C., Seinfeld, J. H., Hameri, K., Pirjola, L., Kulmala, M., Jennings, S. G., and Hoffmann, T.: Marine aerosol formation from biogenic iodine emissions, Nature, 417, 632-636, 2002.

Pierce, J. R., Riipinen, I., Kulmala, M., Ehn, M., Petäjä, T., Junninen, H., Worsnop, D. R., and Donahue, N. M.: Quantification of the volatility of secondary organic compounds in ultrafine particles during nucleation events, Atmos. Chem. Phys., 11, 90199036, doi:10.5194/acp-11-9019-2011, 2011.

Pierce, J. R., Leaitch, W. R., Liggio, J., Westervelt, D. M., Wainwright, C. D., Abbatt, J. P. D., Ahlm, L., Al-Basheer, W., Cziczo, D. J., Hayden, K. L., Lee, A. K. Y., Li, S. M., Russell, L. M., Sjostedt, S. J., Strawbridge, K. B., Travis, M., Vlasenko, A., Wentzell, J. J. B., Wiebe, H. A., Wong, J. P. S., and Macdonald, A. M.: Nucleation and condensational growth to CCN sizes during a sustained pristine biogenic SOA event in a forested mountain valley, Atmos. Chem. Phys., 12, 3147-3163, doi:10.5194/acp-12-3147-2012, 2012.

Pikridas, M., Riipinen, I., Hildebrandt, L., Kostenidou, E., Manninen, H., Mihalopoulos, N., Kalivitis, N., Burkhart, J. F., Stohl, A., Kulmala, M., and Pandis, S. N.: New particle formation at a remote site in the eastern Mediterranean, J. Geophys. Res., 117, D12205, doi:10.1029/2012jd017570, 2012.

Riipinen, I., Pierce, J. R., Yli-Juuti, T., Nieminen, T., Hakkinen, S., Ehn, M., Junninen, H., Lehtipalo, K., Petaja, T., Slowik, J., Chang, R., Shantz, N. C., Abbatt, J., Leaitch, W. R., Kerminen, V. M., Worsnop, D. R., Pandis, S. N., Donahue, N. M., and Kulmala, M.: Organic condensation: a vital link connecting aerosol formation to cloud condensation nuclei (CCN) concentrations, Atmos. Chem. Phys., 11, 3865-3878, doi:10.5194/acp-11-38652011, 2011.

Riipinen, I., Yli-Juuti, T., Pierce, J. R., Petaja, T., Worsnop, D. R., Kulmala, M., and Donahue, N. M.: The contribution of organics to atmospheric nanoparticle growth, Nature Geoscience, 5, 453458, doi:10.1038/ngeo1499, 2012.

Schichtel, B. A., Malm, W. C., Bench, G., Fallon, S., McDade, C. E., Chow, J. C., and Watson, J. G.: Fossil and contemporary fine particulate carbon fractions at 12 rural and urban sites in the United States, J. Geophys. Res.-Atmos., 113, D02311, doi:10.1029/2007jd008605, 2008.

Setyan, A., Zhang, Q., Merkel, M., Knighton, W. B., Sun, Y., Song, C., Shilling, J. E., Onasch, T. B., Herndon, S. C., Worsnop, D. R., Fast, J. D., Zaveri, R. A., Berg, L. K., Wiedensohler, A., Flowers, B. A., Dubey, M. K., and Subramanian, R.: Characterization of submicron particles influenced by mixed biogenic and anthropogenic emissions using high-resolution aerosol mass spectrometry: results from CARES, Atmos. Chem. Phys., 12, 8131-8156, doi:10.5194/acp-12-8131-2012, 2012. 
Shilling, J. E., Zaveri, R. A., Fast, J. D., Kleinman, L., Alexander, M. L., Canagaratna, M. R., Fortner, E., Hubbe, J. M., Jayne, J. T., Sedlacek, A., Setyan, A., Springston, S., Worsnop, D. R., and Zhang, Q.: Enhanced SOA formation from mixed anthropogenic and biogenic emissions during the CARES campaign, Atmos. Chem. Phys., 13, 2091-2113, doi:10.5194/acp-13-20912013, 2013.

Smith, J. N., Moore, K. F., Eisele, F. L., Voisin, D., Ghimire, A. K., Sakurai, H., and McMurry, P. H.: Chemical composition of atmospheric nanoparticles during nucleation events in Atlanta, Journal of Geophysical Research: Atmospheres, 110, D22S03, doi:10.1029/2005jd005912, 2005.

Smith, J. N., Dunn, M. J., VanReken, T. M., Iida, K., Stolzenburg, M. R., McMurry, P. H., and Huey, L. G.: Chemical composition of atmospheric nanoparticles formed from nucleation in Tecamac, Mexico: evidence for an important role for organic species in nanoparticle growth, Geophys. Res. Lett., 35, L04808, doi:10.1029/2007GL032523, 2008.

Smith, J. N., Barsanti, K. C., Friedli, H. R., Ehn, M., Kulmala, M., Collins, D. R., Scheckman, J. H., Williams, B. J., and McMurry, P. H.: Observations of aminium salts in atmospheric nanoparticles and possible climatic implications, Proc. Natl. Acad. Sci., 107, 6634-6639, doi:10.1073/pnas.0912127107, 2010.

Spracklen, D. V., Carslaw, K. S., Kulmala, M., Kerminen, V. M., Mann, G. W., and Sihto, S. L.: The contribution of boundary layer nucleation events to total particle concentrations on regional and global scales, Atmos. Chem. Phys., 6, 5631-5648, doi:10.5194/acp-6-5631-2006, 2006.

Spracklen, D. V., Jimenez, J. L., Carslaw, K. S., Worsnop, D. R., Evans, M. J., Mann, G. W., Zhang, Q., Canagaratna, M. R., Allan, J., Coe, H., McFiggans, G., Rap, A., and Forster, P.: Aerosol Mass Spectrometer constraint on the global secondary organic aerosol budget, Atmos. Chem. Phys., 11, 12109-12136, doi:10.5194/acp-11-12109-201, 2011.

Stanier, C. O., Khlystov, A. Y., and Pandis, S. N.: Nucleation events during the Pittsburgh air quality study: Description and relation to key meteorological, gas phase, and aerosol parameters, Aerosol Sci. Technol., 38, 253-264, doi:10.1080/02786820390229570, 2004.

Vakkari, V., Laakso, H., Kulmala, M., Laaksonen, A., Mabaso, D., Molefe, M., Kgabi, N., and Laakso, L.: New particle formation events in semi-clean South African savannah, Atmos. Chem. Phys., 11, 3333-3346, doi:10.5194/acp-11-3333-2011, 2011.

Volkamer, R., Jimenez, J. L., San Martini, F., Dzepina, K., Zhang, Q., Salcedo, D., Molina, L. T., Worsnop, D. R., and Molina, M. J.: Secondary organic aerosol formation from anthropogenic air pollution: Rapid and higher than expected, Geophys. Res. Lett., 33, L17811, doi:10.1029/2006g1026899, 2006.

Weber, R. J., McMurry, P. H., Mauldin, R. L., Tanner, D. J., Eisele, F. L., Clarke, A. D., and Kapustin, V. N.: New Particle Formation in the Remote Troposphere: A Comparison of Observations at Various Sites, Geophys. Res. Lett., 26, 307-310, doi:10.1029/1998GL900308, 1999.

Wen, J., Zhao, Y., and Wexler, A. S.: Marine particle nucleation: Observation at Bodega Bay, California, J. Geophys. Res., 111, D08207, doi:10.1029/2005jd006210, 2006.

Wiedensohler, A., Birmili, W., Nowak, A., Sonntag, A., Weinhold, K., Merkel, M., Wehner, B., Tuch, T., Pfeifer, S., Fiebig, M., Fjäraa, A. M., Asmi, E., Sellegri, K., Depuy, R., Venzac, H., Vil- lani, P., Laj, P., Aalto, P., Ogren, J. A., Swietlicki, E., Williams, P., Roldin, P., Quincey, P., Hüglin, C., Fierz-Schmidhauser, R., Gysel, M., Weingartner, E., Riccobono, F., Santos, S., Grüning, C., Faloon, K., Beddows, D., Harrison, R., Monahan, C., Jennings, S. G., O’Dowd, C. D., Marinoni, A., Horn, H. G., Keck, L., Jiang, J., Scheckman, J., McMurry, P. H., Deng, Z., Zhao, C. S., Moerman, M., Henzing, B., de Leeuw, G., Löschau, G., and Bastian, S.: Mobility particle size spectrometers: harmonization of technical standards and data structure to facilitate high quality long-term observations of atmospheric particle number size distributions, Atmos. Meas. Tech., 5, 657-685, doi:10.5194/amt5-657-2012, 2012.

Wu, Z., Hu, M., Liu, S., Wehner, B., Bauer, S., Ma ßling, A., Wiedensohler, A., Petäjä, T., Dal Maso, M., and Kulmala, M.: New particle formation in Beijing, China: Statistical analysis of a 1-year data set, J. Geophys. Res., 112, D09209, doi:10.1029/2006jd007406, 2007.

Yue, D. L., Hu, M., Zhang, R. Y., Wang, Z. B., Zheng, J., Wu, Z. J., Wiedensohler, A., He, L. Y., Huang, X. F., and Zhu, T.: The roles of sulfuric acid in new particle formation and growth in the mega-city of Beijing, Atmos. Chem. Phys., 10, 4953-4960, doi:10.5194/acp-10-4953-2010, 2010.

Zaveri, R. A., Shaw, W. J., Cziczo, D. J., Schmid, B., Ferrare, R. A., Alexander, M. L., Alexandrov, M., Alvarez, R. J., Arnott, W. P., Atkinson, D. B., Baidar, S., Banta, R. M., Barnard, J. C., Beranek, J., Berg, L. K., Brechtel, F., Brewer, W. A., Cahill, J. F., Cairns, B., Cappa, C. D., Chand, D., China, S., Comstock, J. M., Dubey, M. K., Easter, R. C., Erickson, M. H., Fast, J. D., Floerchinger, C., Flowers, B. A., Fortner, E., Gaffney, J. S., Gilles, M. K., Gorkowski, K., Gustafson, W. I., Gyawali, M., Hair, J., Hardesty, R. M., Harworth, J. W., Herndon, S., Hiranuma, N., Hostetler, C., Hubbe, J. M., Jayne, J. T., Jeong, H., Jobson, B. T., Kassianov, E. I., Kleinman, L. I., Kluzek, C., Knighton, B., Kolesar, K. R., Kuang, C., Kubátová, A., Langford, A. O., Laskin, A., Laulainen, N., Marchbanks, R. D., Mazzoleni, C., Mei, F., Moffet, R. C., Nelson, D., Obland, M. D., Oetjen, H., Onasch, T. B., Ortega, I., Ottaviani, M., Pekour, M., Prather, K. A., Radney, J. G., Rogers, R. R., Sandberg, S. P., Sedlacek, A., Senff, C. J., Senum, G., Setyan, A., Shilling, J. E., Shrivastava, M., Song, C., Springston, S. R., Subramanian, R., Suski, K., Tomlinson, J., Volkamer, R., Wallace, H. W., Wang, J., Weickmann, A. M., Worsnop, D. R., Yu, X. Y., Zelenyuk, A., and Zhang, Q.: Overview of the 2010 Carbonaceous Aerosols and Radiative Effects Study (CARES), Atmos. Chem. Phys., 12, 7647-7687, doi:10.5194/acp-12-7647-2012, 2012.

Zhang, Q., Stanier, C. O., Canagaratna, M. R., Jayne, J. T., Worsnop, D. R., Pandis, S. N., and Jimenez, J. L.: Insights into the chemistry of new particle formation and growth events in Pittsburgh based on aerosol mass spectrometry, Environ. Sci. Technol., 38, 4797-4809, doi:10.1021/es035417u, 2004a.

Zhang, Q., Worsnop, D. R., Canagaratna, M. R., and Jimenez, J. L.: Hydrocarbon-like and oxygenated organic aerosols in Pittsburgh: insights into sources and processes of organic aerosols, Atmos. Chem. Phys., 5, 3289-3311, doi:10.5194/acp-5-32892005, 2005.

Zhang, Q., Jimenez, J. L., Canagaratna, M. R., Allan, J. D., Coe, H., Ulbrich, I., Alfarra, M. R., Takami, A., Middlebrook, A. M., Sun, Y. L., Dzepina, K., Dunlea, E., Docherty, K., DeCarlo, P. F., Salcedo, D., Onasch, T., Jayne, J. T., Miyoshi, 
T., Shimono, A., Hatakeyama, S., Takegawa, N., Kondo, Y., Schneider, J., Drewnick, F., Borrmann, S., Weimer, S., Demerjian, K., Williams, P., Bower, K., Bahreini, R., Cottrell, L., Griffin, R. J., Rautiainen, J., Sun, J. Y., Zhang, Y. M., and Worsnop, D. R.: Ubiquity and dominance of oxygenated species in organic aerosols in anthropogenically-influenced Northern Hemisphere midlatitudes, Geophys. Res. Lett., 34, L13801, doi:10.1029/2007GL029979, 2007.

Zhang, X. F., Smith, K. A., Worsnop, D. R., Jimenez, J. L., Jayne, J. T., Kolb, C. E., Morris, J., and Davidovits, P.: Numerical characterization of particle beam collimation: Part II - Integrated aerodynamic-lens-nozzle system, Aerosol Sci. Technol., 38, 619-638, doi:10.1080/02786820490479833, 2004b.

Zhang, Y. M., Zhang, X. Y., Sun, J. Y., Lin, W. L., Gong, S. L., Shen, X. J., and Yang, S.: Characterization of new particle and secondary aerosol formation during summertime in Beijing, China, Tellus Ser. B-Chem. Phys. Meteorol., 63, 382-394, 10.1111/j.1600-0889.2011.00533.x, 2011.
Ziemba, L. D., Griffin, R. J., Cottrell, L. D., Beckman, P. J., Zhang, Q., Varner, R. K., Sive, B. C., Mao, H., and Talbot, R. W.: Characterization of aerosol associated with enhanced small particle of number concentrations in a suburban forested environment, J. Geophys. Res.-Atmos., 115, D12206, doi:10.1029/2009JD012614, 2010.

Zollner, J. H., Glasoe, W. A., Panta, B., Carlson, K. K., McMurry, P. H., and Hanson, D. R.: Sulfuric acid nucleation: power dependencies, variation with relative humidity, and effect of bases, Atmos. Chem. Phys., 12, 4399-4411, doi:10.5194/acp-12-43992012, 2012. 